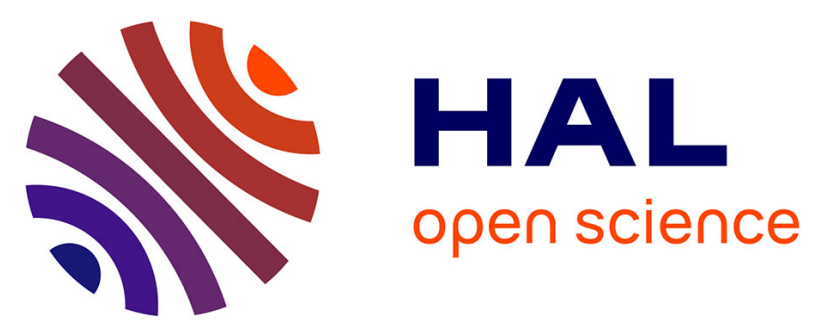

\title{
Development of miniaturized immunoassay: Influence of surface chemistry and comparison with enzyme-linked immunosorbent assay and Western blot
}

Graziella El Khoury, Emmanuelle Laurenceau, Yann Chevolot, Yves Mérieux, Agnès Desbos, Nicole Fabien, Dominique Rigal, Eliane Souteyrand, Jean-Pierre Cloarec

\section{To cite this version:}

Graziella El Khoury, Emmanuelle Laurenceau, Yann Chevolot, Yves Mérieux, Agnès Desbos, et al.. Development of miniaturized immunoassay: Influence of surface chemistry and comparison with enzyme-linked immunosorbent assay and Western blot. Analytical Biochemistry, 2010, 400 (1), pp.10 - 18. 10.1016/j.ab.2010.01.013 . hal-01850000

\section{HAL Id: hal-01850000 https://hal.science/hal-01850000}

Submitted on 26 Apr 2019

HAL is a multi-disciplinary open access archive for the deposit and dissemination of scientific research documents, whether they are published or not. The documents may come from teaching and research institutions in France or abroad, or from public or private research centers.
L'archive ouverte pluridisciplinaire HAL, est destinée au dépôt et à la diffusion de documents scientifiques de niveau recherche, publiés ou non, émanant des établissements d'enseignement et de recherche français ou étrangers, des laboratoires publics ou privés. 
Development of miniaturized immunoassay: influence of surface chemistry and comparison with ELISA and Westernblot

Short title: Surface chemistry for protein microarrays

Subject category: Immunoassays that introduce a unique approach

Graziella El Khoury ${ }^{1}$, Emmanuelle Laurenceau ${ }^{1}$, Yann Chevolot ${ }^{1}$, Yves Mérieux ${ }^{2}$, Agnès Desbos ${ }^{3}$, Nicole Fabien ${ }^{3}$, Dominique Rigal ${ }^{2}$, Eliane Souteyrand ${ }^{1}$, Jean Pierre Cloarec ${ }^{1}$

${ }^{1}$ Université de Lyon, Institut des Nanotechnologies de Lyon - INL, UMR CNRS 5270, site Ecole Centrale de Lyon, 36, Avenue Guy de Collongue, Ecully, France

${ }^{2}$ Etablissement Français du Sang - EFS - Lyon, 1-3, Rue du Vercors, 69007 Lyon France

${ }^{3}$ Laboratoire d'Auto-Immunité, Hôpital Lyon-Sud, Hospices Civils de Lyon, 69495 Pierre-Bénite, France

Corresponding Author*: Emmanuelle Laurenceau, Université de Lyon, Institut des Nanotechnologies de Lyon - INL, UMR CNRS 5270, 36, Avenue Guy de Collongue, Ecully, France.

Tel +33 (0)4 72186240

Fax : +33 (0)4 78433593

E-mail Adresse: emmanuelle.laurenceau@ec-Iyon.fr

* to Whom proof should be sended 


\section{Abstract}

Protein microarray technology provides a useful approach for the simultaneous serodetection of various antibodies in low sample volumes. In order to implement functional protein microarrays, appropriate surface chemistry has to be designed so that both the protein structure and the biological activity can be retained. In the present study, two surface chemistries for protein microarrays and immunofluorescent assays have been developed. Glass slides were functionalized with NHS-ester via a monofunctional silane or Maleic Anhydride-alt-Methyl Vinyl Ether (MAMVE) copolymer to allow covalent grafting of histone proteins. Analytical performance of these microarrays were then evaluated for the detection of antihistone autoantibodies present in the sera of patients suffering from a systemic autoimmune disease, i.e. systemic lupus erythematosus (SLE), and the results compared with classical immunoassays, ELISA and western blot. The detection limit of our MAMVE copolymer microarrays was 50 fold lower than the detection limit of the classical ELISA. Furthermore, 100 fold less volume of biological samples was required with these miniaturized immunoassays.

Keywords: Protein microarrays; Autoimmune diseases; MAMVE copolymer ; Surface chemistry ; Protein immobilization 


\section{Introduction}

The detection of single proteins in complex biological solutions (e.g. sera) is usually performed using immunoassays. The most widely used format is ELISA, which has several benefits, such as reproducibility (coefficient of variation between $5-20 \%$ ), sensitivity (dynamic range of 3 logs), a low detection limit (around $1 \mathrm{pg} / \mathrm{mL}$ ) and ease of use (1). However, the standard 96-well plate ELISA has a limited ability to efficiently screen large numbers of proteins, particularly when sample volumes are limited. In addition, proteins are immobilized on a solid support by physical adsorption (non-covalent binding) in ELISA, leading to a low surface density and a partial lost of biological activity due to protein denaturation $(2,3)$. The methods used in protein microarray technology should overcome some of these limitations $(3,4)$. Protein microarrays allow for the high-throughput and parallel screening of various biological interactions with tiny volumes of sample and reagents. Therefore, multiplexed and miniaturized immunoassays have the potential to become a powerful tool for the screening and validation of biomarkers in complex diseases such as cancer and autoimmune disease $(5,6)$.

During the diagnosis of autoimmune diseases, such as systemic lupus erythematosus (SLE) or arthritis rheumatoid, autoantibodies are frequently directed against certain cytoplasmic or nuclear antigens of the cell (double and single stranded DNA, histones, ribonucleoproteins, etc.). Previously, proteins such as histones, ribonucleoproteins and other biomolecules (peptides, DNA, etc.) have been immobilized by physical adsorption onto poly-L-Lysine or nitrocellulose-coated (FAST slide) glass slides. These microarrays were then used for the detection of autoantibodies in the serum of patients with various autoimmune diseases $(6,7)$. 
Autoantigen microarrays are ideally suited to autoantibody profiling in complex solution like serum, within a single experiment.

A crucial parameter in the development of protein microarrays is the design of well defined surface chemistry, which allows the biological activity of proteins to be retained when immobilized on solid supports (e.g. membranes, glass slides). A large variety of surface modifications and chemistries have been employed to immobilize proteins onto glass slides (8), and ideally these immobilization schemes must have high binding capacity, an ability to retain protein activity, a low variability between slides and a high signal-to-noise for detection (9). These previous studies were performed on commercially available slide surfaces such as poly-L-lysine $(10,11)$, SuperEpoxy $(11,12)$, SuperAldehyde (10), Hydrogel (10), Full Moon and FAST® slides $(7,13,14)$, as well as on "home-made" modifications such as silanized, PEGEpoxy and dendrimer slides (15). Seurynk-Servoss et al. have tested the immobilization of 23 antibodies on 17 commercially available modified glass sides. They studied the morphology of spots, slide and spot background noise, limit of detection (LOD) and reproducibility. Their results show that all these parameters varied with the surface chemistry. For example, the LOD varied from 0.1 to 475 $\mathrm{pg} / \mathrm{mL}$ and the coefficients of variation ranged from 16 to $40 \%$. So the activity of the immobilized antibodies and the quality of the produced data were affected by the surface properties. According to their results, aldehyde-silane, poly-L-lysine or aminosilane modified glass slide give superior results in sandwich ELISA microarray (9). In another study, Balboni et al. have evaluated performances of 24 surfaces with about 50 autoantigens. They also found that the quality of the data is dependent on surface chemistry (16). 
The oriented immobilization of proteins can be performed by using affinity tags, such as for example His, GST or biotin tag on Ni-NTA (Ni-nitrilotriacetic acid), gluthatione or avidin modified slides, respectively (for review see (17)).

Therefore, it is very important to adapt the surface chemistry of the slide in a microarray to the nature of the protein to be immobilized. The present work consists of exploring two surface chemistries in order to functionalize glass slides for the covalent immobilization of histone proteins:

- N-hydroxysuccinimide (NHS) ester surface via a monofunctional silane. Monofunctional silane cannot self polymerize (18). The resulting modified surface is robust (can withstand on-chip peptide and DNA synthesis), non damaged under stringency washings and reproducible $(19,20)$

- aminated surface modified with Maleic Anhydride-alt-Methyl Vinyl Ether (MAMVE) copolymer. MAMVE copolymer presents anhydride moieties which highly react towards primary amino groups. The copolymer has been previously used for the modification of biomolecules (e.g. peptides, proteins) in various applications, such as the immobilization of bioconjugates on ELISA microtiter plates $(21,22)$. However, in these previous studies the bioconjugates were immobilized by physical adsorption onto the polystyrene surfaces.

The performance of the protein microarrays developed herein was evaluated for the detection of anti-histone antibodies in human sera of patients with SLE, and the analytical performances of these miniaturized immunoassays was then compared to those of classical ELISA and western blot on patient sera.

\section{Materials and methods}




\subsection{Reagents and biomolecules}

Histone proteins from calf thymus [H1 (type III-S), H3 (type VIII-S) and unfractionated whole histone (type II-A)]; BSA lyophilized powder, 4-chloro-1-naphtol (30 mg tablets) DMSO anhydrous, $\geq 99.9 \%$, and $0.01 \mathrm{M} \mathrm{PBS,} \mathrm{pH} 7.4$ at $25^{\circ} \mathrm{C}$ ( $0.0027 \mathrm{M}$ potassium chloride and $0.138 \mathrm{M}$ sodium chloride) were all supplied from Sigma-Aldrich (St. Quentin Fallavier, France).

SDS, sodium bicarbonate $\mathrm{NaHCO}_{3}\left(\mathrm{M}_{\mathrm{r}} 84.01 \mathrm{~g} / \mathrm{mol}\right)$, sodium carbonate $\mathrm{Na}_{2} \mathrm{CO}_{3}\left(\mathrm{M}_{\mathrm{r}}\right.$ $105.99 \mathrm{~g} / \mathrm{mol}), \quad \mathrm{N}$-hydroxysuccinimide (NHS), N,N'-diisopropylcarbodiimide, tetrahydrofuran (THF), purum grade, were obtained from Fluka (St. Quentin Fallavier, France).

Tween $^{\circledR} 20$ was purchased from Roth-Sochiel (Lauterbourg, France). Ortho-phenylenediamine (OPD, 2 mg tablets) was purchased from BD Biosciences Pharmingen (Le Pont-de-Claix, France). Hydrogen peroxide $\left(\mathrm{H}_{2} \mathrm{O}_{2}\right)$ solution 30 Volume was obtained from Gilbert laboratories (Hérouville Saint - Claire, France). Maleic anhydride-alt-methyl vinyl ether copolymer [P (MAMVE); $M_{r} 67000 \mathrm{~g} / \mathrm{mol}$ ] was provided by Biomérieux - CNRS - UMR 2714 (Ecole Normale Supérieure, Lyon, France).

Ultrapure water (18.2 M $\Omega$ ) was delivered by an Elga water system.

Rabbit anti-histone $\mathrm{H} 3$ antibody (IgG fraction of antiserum, buffered aqueous solution) was purchased from Sigma-Aldrich. Cy3 goat anti-rabbit $\lg G[H+L]$ (2 mg/mL) and Cy3 goat anti-human IgG [H $+\mathrm{L}](2 \mathrm{mg} / \mathrm{mL})$, Horseradish Peroxidase (HRP) goat anti-rabbit $\lg G[\mathrm{H}+\mathrm{L}](2 \mathrm{mg} / \mathrm{mL})$ and HRP goat anti-human $\lg G[\mathrm{H}+\mathrm{L}]$ (2 mg/mL) were all purchased from Interchim (Montlucon, France). 40\% acrylamidebis acrylamide solution (37.5:1) was supplied from Bio-Rad. 
Microscope borosilicate flat glass slides $(76 \times 26 \times 1 \mathrm{~mm})$ were obtained from Schott (Mainz, Germany). Microwell plates, Nunc MaxiSorp (96 wells, flat bottom) were supplied from Nunc (distributed by VWR). Nitrocellulose membranes $(0.2 \mu \mathrm{m})$ were supplied from Bio-Rad (Marnes-la-Coquette, France).

\subsection{Buffers}

$0.01 \mathrm{M}$ of PBS or PBS (1X) was prepared by dissolving the content of one pouch of dried powder in $1 \mathrm{~L}$ of ultrapure water.

$0.05 \mathrm{M}$ and $0.02 \mathrm{M}$ sodium carbonate buffers $\left(\mathrm{NaHCO}_{3} / \mathrm{Na}_{2} \mathrm{CO}_{3}\right), \mathrm{pH} 9.6$ and $\mathrm{pH}$ 10.7, respectively, were prepared from $0.1 \mathrm{M} \mathrm{NaHCO}_{3}$ and $0.1 \mathrm{M} \mathrm{Na}_{2} \mathrm{CO}_{3}$ solutions in ultrapure water.

Blocking solution was prepared by dissolving $2 \mathrm{~g}$ of BSA in $100 \mathrm{~mL}$ PBS buffer. Washing buffer was $0.01 \mathrm{M}$ PBS, $0.05 \%$ Tween $^{\circledR} 20$ (PBS-T), pH 7.4.

\subsection{Serum samples}

Eight sera of SLE patients were obtained from a sera collection (Centre de Ressources Biologiques, CRB Immunobiothèque) that was approved by the Institutional Review Board of the Hospices Civils de Lyon. Written informed consent was obtained from all patients. Six sera from healthy donors were kindly provided by Etablissement Français du Sang (Lyon, France). All sera were stored at $-80^{\circ} \mathrm{C}$.

\subsection{Western blot technique}

Unfractionated whole histone (20 $\mu \mathrm{g} / \mathrm{lane})$ was run on SDS-PAGE (15\% polyacrylamide gel) at $200 \mathrm{~V}$ for $50 \mathrm{~min}$, and the resolved proteins were transferred to nitrocellulose membranes. The sheets were soaked with $1 \%$ non-fat milk PBS-T (30 min, at room temperature) to block the free protein binding sites. The 
nitrocellulose strips were then incubated $(90 \mathrm{~min})$ with the human sera (dilution 1:100).

The antigen-antibody complexes were probed with HRP-conjugated anti-human IgG (dilution 1:400) and revealed with the peroxydase substrate (4-chloro-1-naphtol $0.06 \%(\mathrm{w} / \mathrm{v}) ; \mathrm{H}_{2} \mathrm{O}_{2} 0.033 \%(\mathrm{v} / \mathrm{v})$ ), for $20 \mathrm{~min}$ in the dark, at room temperature.

\subsection{ELISA technique}

The ELISA microplate was coated overnight at $4^{\circ} \mathrm{C}$ with either $100 \mu \mathrm{L}$ of histone $\mathrm{H} 1$ or histone $\mathrm{H} 3$ solution at $5 \mu \mathrm{g} / \mathrm{mL}$ or $10 \mu \mathrm{g} / \mathrm{mL}$ in $0.1 \mathrm{~N}$ carbonate buffer, $\mathrm{pH}$ 9.6. After discarding the antigen solution, the microplate was washed three times with $200 \mu \mathrm{L}$ of PBS-T buffer and incubated with $200 \mu \mathrm{L}$ of blocking solution for $2 \mathrm{hrs}$ at $37^{\circ} \mathrm{C}$. After washing with PBS-T buffer, wells were incubated for $1 \mathrm{hr}$ at $37^{\circ} \mathrm{C}$ with $100 \mu \mathrm{L}$ of polyclonal anti-histone $\mathrm{H} 3$ antibody at different dilutions $\left(1: 10^{8}\right.$ to $\left.1: 10^{2}\right)$ in a $1 \%$ BSA/PBS-T solution. The microplate was then washed three times with $200 \mu \mathrm{L}$ of PBS-T buffer and incubated with $100 \mu \mathrm{L}$ of HRP goat anti-rabbit IgG diluted at $1: 10^{4}$, for $1 \mathrm{hr}$ at $37^{\circ} \mathrm{C}$, then washed six times with $200 \mu \mathrm{L}$ of PBS-T buffer. A volume of $100 \mu \mathrm{L}$ of OPD solution was added and the microplate was incubated for $20 \mathrm{~min}$ in the dark at room temperature. The reaction was stopped by adding $100 \mu \mathrm{L}$ of $1 \mathrm{~N}$ $\mathrm{H}_{2} \mathrm{SO}_{4}$ solution. Optical densities (OD) were read at $492 \mathrm{~nm}$ with an ELISA microplate reader (Metertech $\Sigma 960$ ).

Human sera tested in ELISA were diluted at $1: 10^{2}$ in $1 \%$ BSA/PBS-T solution.

\subsection{Chemical functionalization of glass slides}

Glass slides (borosilicate, Schott) were functionalized according to previous protocols $(18,23)$. In brief, the supports were silanized with tert-butyl-11- 
(dimethylamino)silylundecanoate. Terbutyl esters were then hydrolyzed with formic acid $7 \mathrm{~h}$ at room temperature. The slides were washed with dichloromethane for $10 \mathrm{~min}$ in ultrasonic bath, followed by $10 \mathrm{~min}$ in deionized water (enough volume was added to completely immerse the slides). Activation of carboxylic acid was carried out with a mixture of NHS/DIC (molar ratio of 1:1, $0.1 \mathrm{M}$ ) in THF, overnight at room temperature, washed $10 \mathrm{~min}$ in tetrahydrofuran and $10 \mathrm{~min}$ in dichloromethane, under sonication, to obtain NHS activated esters.

The slides were incubated in a $0.1 \mathrm{M}$ solution of aminated Jeffamine D-230 (polyoxypropylenediamine) linker, overnight at room temperature. The surfaces were then washed for $30 \mathrm{~min}$ with $0.1 \% \mathrm{SDS}$ at $70^{\circ} \mathrm{C}$ and rinsed with ultrapure water.

The generated amino modified surfaces are then incubated in $0.02 \mathrm{M}$ sodium carbonate solution, $\mathrm{pH} 10.7$, for $1 \mathrm{hr}$, at room temperature to deprotonate amine functions. Slides were then dried by centrifugation for $3 \mathrm{~min}$ at $1300 \mathrm{rpm}$, and washed in DMSO for 10 min under sonication, at room temperature. Then, they were incubated in MAMVE solutions in DMSO at different concentrations $(1,3$ and $5 \mathrm{mg} / \mathrm{mL}$ ), overnight at room temperature. Finally, the slides were washed with PBS $1 \mathrm{X}$ and dried by centrifugation.

\subsection{Immunoassays on protein microarrays}

Protein solutions of histone $\mathrm{H} 1$ or $\mathrm{H} 3$ were prepared in PBS $1 \mathrm{X}$ at two different concentrations ( 0.5 and $1 \mathrm{mg} / \mathrm{mL})$. A volume of $1 \mu \mathrm{L}$ of each solution, as well as of the dilution buffer (PBS 1X) for a negative control, was manually spotted onto NHS esters (Figure 1.A) or MAMVE modified glass slides (Figure 1.B). Spot diameter was approximately $2 \mathrm{~mm}$. Protein solutions were allowed to react overnight at room temperature on NHS ester slides, and for $3 \mathrm{hrs}$ at $37^{\circ} \mathrm{C}$ on MAMVE slides in a water 
saturated atmosphere. These reaction conditions are typical for protein-MAMVE copolymer coupling (21). The slides were then washed and sonicated $1 \times 3$ min with PBS-T, 1 min with ultrapure water and dried by centrifugation for 3 min at $1300 \mathrm{rpm}$. The slides were blocked with $2 \%$ BSA / PBS solution and left to incubate $2 \mathrm{~h}$ at $37^{\circ} \mathrm{C}$, then washed and sonicated with PBS-T, ultrapure water and dried by centrifugation. Spots were then incubated with $1 \mu \mathrm{L}$ of either rabbit anti-histone $\mathrm{H} 3$ purified polyclonal antibody (dilution between $1: 10^{8}$ and $1: 10^{4}$ in PBS-T / 1\% BSA solution) or human sera diluted at $1: 10^{2}$. The slides were left to react for $1 \mathrm{hr}$ at $37^{\circ} \mathrm{C}$ in water saturated atmosphere, then thoroughly rinsed with water, washed and sonicated for $3 \times 3$ min with PBS-T, 1 min with water and dried by centrifugation. Spots were then incubated with either Сy3 goat anti-rabbit IgG or Сy3 anti-human IgG, diluted at $1: 10^{2}$ in PBS-T, for $1 \mathrm{hr}$ at $37^{\circ} \mathrm{C}$, in water saturated atmosphere. The slides were washed $6 \times 2$ min with PBS-T, 1 min with water under sonication and dried by centrifugation for $3 \mathrm{~min}$ at $1300 \mathrm{rpm}$.

\subsection{Fluorescence scanning and image analysis}

Slides were scanned with GenePix ${ }^{\circledR}$ Personal $4100 A$ microarray scanner (Axon Instruments / Molecular Devices, Union City, USA) at a spatial resolution of $20 \mu \mathrm{m}$ pixel and a PhotoMultiplier Tube (PMT) gain of 500. Excitation and emission wavelengths were $532 \mathrm{~nm}$ and $570 \mathrm{~nm}$ respectively, corresponding to Cy3 molecule. Images were analyzed with GenePix Pro 6.0 software. The complete data set analyzed consisted of the average pixel fluorescence intensities of spots. Each measurement point presented in this article corresponds to the average of four independent experiments performed in duplicate. 


\subsection{Statistical analysis}

Performances of ELISA and protein microarrays were compared in term of reproducibility, repeatability, low detection limit, dynamic range and sensitivity.

Repeatability and reproducibility were evaluated in percentile as the coefficients of variation (CV) intra- and inter-assay, respectively:

$\% \mathrm{CV}=(\mathrm{SD} / \mathrm{Mean}) \times 100$.

CV intra- and inter-assay were considered as acceptable for values lower then $8 \%$ and $15 \%$, respectively (24).

The threshold value for the determination of low limit of detection was calculated from the mean of signal values (OD or fluorescence intensity) of negative controls (spots or wells of dilution buffer). Threshold of positivity (cut-off) for immunoassays performed with human sera was calculated from the mean of negative sera values of healthy donors (25).

Threshold or cut-off $=$ Mean $+t_{0.01} S D \sqrt{ }(n+1 / n)$

Thresholds were calculated with $99 \%$ confidence interval around the mean $(\alpha=0.01$ in Student's t-distribution for $\mathrm{n}-1$ degree of freedom); $\mathrm{n}$ : number of test points or negative controls.

In order to compare the results obtained with ELISA and protein microarrays, a ratio was calculated for each serum sample: Ratio = Mean / Cut-off. The mean was also calculated from OD or fluorescence intensities of negative sera (25). A serum sample was considered as positive if the corresponding ratio was higher than 1 .

The dynamic range corresponded to the ratio of high detection limit over low detection limit of each immunoassay. The sensitivity is given by the slope of the curve $[O D$ or fluorescence intensity $=f$ (dilution factor)] in the linear zone. 


\section{Results and discussion}

\subsection{Optimization of protein immobilization conditions onto functionalized glass}

slides

Performance (limit of detection, reproducibility, etc.) of ester activated and MAMVE functionalized glass slides were first evaluated for the biological activity of immobilized histone proteins versus anti-histone antibodies, and compared to the performances of a classical ELISA also used for detection of these proteins.

\subsubsection{ELISA}

The biological model chosen in this study was first validated and characterized with classical ELISA technique. For this purpose, biological interaction of anti-histone $\mathrm{H} 3$ antibody was evaluated with either histone $\mathrm{H} 1$ or $\mathrm{H} 3$. Histone $\mathrm{H} 1$ served as a negative control to test the specificity of anti-histone $\mathrm{H} 3$ antibody for histone $\mathrm{H} 3$. Histone $\mathrm{H} 1$ and $\mathrm{H} 3$ proteins were adsorbed at $5 \mu \mathrm{g} / \mathrm{mL}$ and $10 \mu \mathrm{g} / \mathrm{mL}$ in microplate wells, and dilutions of rabbit $\lg G$ polyclonal antibody ranging from $10^{-8}$ to $10^{-2}$ were added. Results obtained after revelation with HRP anti-rabbit IgG secondary antibody are presented in Figure 2.A.

As expected, anti-H3 antibody interacts specifically with histone $\mathrm{H} 3$ in a dosedependent way for dilution factors of anti-H3 antibody lower than $10^{-3}$. No interaction with histone $\mathrm{H} 1$ is detected in the dilution range tested. Very low non-specific adsorption of antibodies is observed on the microplate surface as indicated by the low OD values ( 0.01 a.u) obtained for wells tested with the dilution buffer. In addition, according to the calculated CV values of intra- and inter-assays $(7.3 \pm 0.6$ $\%$ and $11 \pm 2 \%$, respectively) we notice a good reproducibility of the ELISA technique. Moreover, as shown in Figure 2.A, the lower limit of detection (LOD) of 
histone $\mathrm{H} 3$ is reached for the antibody dilution factor at $10^{-6}$. The dynamic range of the assays ranges from 100 to 300 , as described in the literature. The sensitivity of the assays is similar for protein concentrations and is $0.4 \mathrm{a} . \mathrm{u} / \mathrm{unit}$ of dilution factor. Based on these results, histone proteins were immobilized at $5 \mu \mathrm{g} / \mathrm{mL}$ in subsequent ELISA tests.

\subsubsection{Immunoassays on NHS ester functionalized surfaces}

The ester activated groups on the modified slides allowed for the immobilization of proteins by covalent coupling through their primary amine functional groups ( $\mathrm{N}$-terminal end and amine function of the lysine side chain residues). In order to evaluate the sensitivity and the specificity of the immunoassay on NHS ester functionalized surfaces, immunoassays were performed with the same amount of proteins as in ELISA. Histone $\mathrm{H} 1$ and $\mathrm{H} 3$ were covalently immobilized at $0.5 \mathrm{mg} / \mathrm{mL}$ and $1 \mathrm{mg} / \mathrm{mL}$ on NHS ester functionalized surface (required volume was $1 \mu \mathrm{L}$ versus $100 \mu \mathrm{L}$ in ELISA) and an anti-histone $\mathrm{H} 3$ antibody dilution ranging from $10^{-8}$ to $10^{-2}$ was tested. Results displayed as the mean of fluorescence intensity versus the primary antibody dilution are shown in Figure 2.B. The fluorescence intensity increased with histone $\mathrm{H} 3$ and anti-histone $\mathrm{H} 3$ antibody concentrations, indicating the specificity and dose-dependent interaction between the antigen and its antibody. The signals relative to non-specific adsorption and interaction between histone $\mathrm{H} 1$ and anti-H3 antibody were not significant. The LOD of histone $\mathrm{H} 3$ was reached for the antibody dilution factors of $3 \times 10^{-6}$ for both protein concentrations. The dynamic range corresponding to the ratio of high detection limit over low detection limit was 333. 


\subsubsection{Immunoassays on MAMVE functionalized surfaces}

Surface modification with MAMVE copolymer was achieved through covalent coupling between the anhydride moieties of the copolymer and the amine groups of the slides. Proteins can then be immobilized on the functionalized surface through their primary amine functional groups ( $\mathrm{N}$-terminal end and amine function of lysine residues side chains), by reacting with the remaining anhydride moieties of the copolymer (Figure 1.B).

In order to develop immunoassays on MAMVE functionalized surfaces, the immobilization concentration of the copolymer on aminated slides had to be optimized. Taking into account previous results (data not shown), three concentrations of MAMVE (1, 3 and $5 \mathrm{mg} / \mathrm{mL})$ were tested with two concentrations of histone $\mathrm{H} 3$ protein $(0.5$ and $1 \mathrm{mg} / \mathrm{mL})$, corresponding to the same amount of protein used in ELISA, and anti-histone $\mathrm{H} 3$ antibody dilutions between $10^{-8}$ and $10^{-4}$. Results are reported on Figure 3. Regardless of the copolymer concentration, a very low non-specific adsorption was measured, as can be seen with the dilution buffer samples; threshold values are comparable $\left(7.6 \times 10^{5}\right.$ a.u). Comparison of the graphs indicates that the fluorescence signals, which are proportional to the biological interaction between the anti-histone $\mathrm{H} 3$ antibody and the histone $\mathrm{H} 3$, vary according to protein and MAMVE concentrations. For slides substituted with MAMVE at $1 \mathrm{mg} / \mathrm{mL}$, results are not significantly different for both histone $\mathrm{H} 3$ concentrations tested. However, more significant variation in the fluorescence signal was observed between both protein concentrations with $3 \mathrm{mg} / \mathrm{mL}$ of MAMVE than with $5 \mathrm{mg} / \mathrm{mL}$ of MAMVE, for the different dilutions of anti-histone $\mathrm{H} 3$ antibody.

Regardless of the polymer and histone concentrations, the dynamic range displayed the same value of 100 corresponding to 2 log scale. But the low limit of detection and 
the sensitivity of the immunoassay depended on the copolymer concentration, indicating that it is an important parameter which affects the performance of the test. Indeed, the reactive moieties of MAMVE copolymer are involved in both substitution on aminated glass slides, and in the covalent coupling with the amino groups of proteins. Their density and spatial distribution, related to polymer concentration, will thus determine the number and the orientation of coupled proteins, and therefore their biological activity. It is likely that the number of coupled proteins and/or the number of coupling sites per protein increase with polymer concentration. During protein immobilization, coupling reactions compete with the hydrolysis of anhydride moieties caused by aqueous conditions (PBS buffer). This hydrolysis reduces the amount of MAMVE reactive groups available for covalent coupling, and generates carboxylate groups. These carboxylate groups increase the solubility of the polymer in aqueous solutions which means that the proteins coupled to the polymer chains can remain in solution rather than close to the surface. This could be one of the reasons why the chemical functionalization with MAMVE copolymer lead improved the low limit of detection of the immunoassay by a factor of 150 compared to the NHS ester functionalized surfaces. The best performances in terms of the LOD $(2 \mathrm{x}$ $10^{-8}$ ) and sensitivity (0.3 a.u./ unit of dilution factor) were obtained for proteins immobilized at a $1 \mathrm{mg} / \mathrm{mL}$ concentration on a glass slide substituted with a $3 \mathrm{mg} / \mathrm{mL}$ concentration of MAMVE copolymer. With a lower concentration in MAMVE copolymer, i.e. $1 \mathrm{mg} / \mathrm{mL}$, the sensitivity of the assay was decreased, suggesting that the decreased density and the spatial distribution of reactive moieties on the copolymer do not permit efficient protein grafting on the surface. On the contrary, a higher concentration in MAMVE copolymer, i.e. $5 \mathrm{mg} / \mathrm{mL}$, reduced the LOD. This result could suggest that a high density of reactive groups on the copolymer can lead 
to the immobilization of the proteins through multiple sites of attachment, thereby decreasing the grafting density of functional immobilized histones, and their biological interactions with the antibodies.

\subsubsection{Comparison of immunoassays performances}

In Table 1, the analytical performances of the standard ELISA are compared with the immunoassays performed on NHS ester and MAMVE modified glass slides for the same amount of deposited histone $\mathrm{H} 3$ per test point: $7 \times 10^{-11}$ mol. For the three assays, coefficients of variation inter-assay are in the same range, indicating that these techniques display comparable and acceptable reproducibility. However, the ELISA technique seems to be slightly better in term of repeatability as indicated by the coefficient of variation intra-assay $(7.3+0.6 \%)$, compared to the NHS ester $(9.7+0.9 \%)$ and MAMVE modified surfaces $(9.4+2.6 \%)$.

Moreover, our surfaces compared favourably with some commercially available surfaces. Indeed, Balboni et al. (16) have tested 24 different surfaces for the immobilisation of nearly 50 autoantigens including histones $\mathrm{H} 3$ and $\mathrm{H} 1$, and tested their biological activity towards monoclonal antibodies and human sera. Among these surfaces, only three exhibited good spot morphology, reproducibility (interslide $\mathrm{CV}$ ), repeatability (intraslide CV), low non-specific adsorption and limit of detection (LOD). Two surfaces were nitrocellulose-based surfaces (FAST and PATH) allowing physical adsorption of proteins. The third surface was functionalized with epoxy groups (SuperEpoxy2) allowing covalent grafting of proteins via their amino groups. Analyses performed with monoclonal antibodies indicate intraslide CV ranging from $7.6 \%$ (FAST) to $9 \%$ (SuperEpoxy2), and interslide CV ranging from $10.5 \%$ (FAST) to $17.8 \%$ (PATH). Both the NHS-ester and the MAMVE surfaces developed in this 
study allowed covalent grafting of proteins via their amino groups and exhibit intraslide and interslide CV of $9-10 \%$ and $11-12 \%$ respectively. However, it should be noted that our study was performed with polyclonal antibodies instead of monoclonal antibodies.

In terms of limit of detection, the MAMVE functionalized surface exhibited a LOD of 2 $\times 10^{-8}$ which was 50 fold lower than ELISA $\left(10^{-6}\right)$, and 150 fold lower than the NHS ester functionalized surface $\left(3 \times 10^{-6}\right)$. Thus, we can reach a LOD ranging from 1:300000 for the NHS-ester surface to 1:50000000 for the MAMVE surface with antiH3 polyclonal antibody. As a comparison, Balboni et al. (16) reached LOD ranging from 0.1 to $475 \mathrm{pg} / \mathrm{mL}$ with monoclonal antibodies. Concerning the dynamic range and the sensitivity of immunoassays, ELISA, NHS ester and MAMVE surfaces displayed similar performances. However, the analyte volume required for each spot on miniaturized immunoassays $(1 \mu \mathrm{L})$ was 100 fold lower than that required for ELISA 96 wells microplate $(100 \mu \mathrm{L})$.

On the basis of these results, we can conclude that the immunoassays performed on the MAMVE functionalized surface significantly improved the performance of the immunoassay especially, in term of the detection limit. Therefore, this novel surface chemistry was next used for the detection of $\lg G$ anti-histone autoantibodies directed against $\mathrm{H} 1$ and $\mathrm{H} 3$ histone classes in the sera of patients with SLE.

\subsection{Evaluation of the performance of MAMVE functionalized protein} microarrays for patient sera analysis: comparison with ELISA and western blot Eight sera of patients with SLE and six sera of healthy donors were analyzed using protein microarrays on MAMVE surfaces, ELISA and western-blot analysis. Histones $\mathrm{H} 1$ and $\mathrm{H} 3$ proteins were immobilized at a concentration of $1 \mathrm{mg} / \mathrm{mL}$ onto glass 
slides functionalized with MAMVE at $3 \mathrm{mg} / \mathrm{mL}$ concentration. The diluted sera of eight patients (P1 - P8) were then incubated and antigen-antibody complexes were fluorescently detected with Cy3 anti-human IgG secondary antibody (Figure 4). The diluted sera were also analyzed by ELISA for the detection of anti-histone $\mathrm{H} 1$ and anti-hsitone $\mathrm{H} 3$ antibodies. Both immunoassays showed good repeatability $(\mathrm{CV}=9 \pm 0.1 \%$ for protein microarray, and $\mathrm{CV}=8.5 \pm 0.7 \%$ for ELISA $)$ and reproducibility (CV $=10 \pm 6 \%$ for protein microarray, and CV $=9 \pm 7 \%$ for ELISA), in accordance with the results previously obtained with purified antibodies.

The results shown in Figure 5 indicate the ratio of fluorescence intensity or OD values / cut-off of positivity. The cut-off of positivity was calculated from the mean of the fluorescence intensity, or OD values obtained from the sera of six healthy donors. Seven of the eight sera samples (P1, P2, P4-P8) tested on the MAMVE functionalized protein microarrays were positive for anti-histone $\mathrm{H} 1$ antibodies and all of the sera samples were positive for anti-histone $\mathrm{H} 3$ antibodies. However, with ELISA, only five of the sera samples (P1, P2, P6-P8) were positive for anti-histone $\mathrm{H} 1$ antibodies and four of the sera samples (P2, P6-P8) were positive for anti-histone $\mathrm{H} 3$ antibodies. Only serum P3 was negative for anti-histone $\mathrm{H} 1$ antibodies using both techniques. Concordant results between MAMVE functionalized protein microarrays and ELISA tests were found in $50 \%$ of the sera samples (sera P2, P6, P7 and P8) for anti-histone $\mathrm{H} 1$ and anti-histone $\mathrm{H} 3$ antibody detection. The discrepancy between the two techniques could be explained by the gain in the lower limit of detection for immunoassays performed on MAMVE functionalized surfaces, as the LOD on this surface is 50 fold lower than that of ELISA. However, some positive sera samples in ELISA displayed higher ratios than obtained with MAMVE functionalized protein microarrays: P2, P6 for the detection of anti-histone $\mathrm{H} 3$ antibodies, and P8 for the 
detection of anti-histone $\mathrm{H} 1$ and anti-histone $\mathrm{H} 3$ antibodies. It is likely that these sera contained high levels of anti-histone $\mathrm{H} 1$ and/or $\mathrm{H} 3$ compared to the others. As we observed (cf table 1), ELISA showed a slightly larger dynamic range and sensitivity than the protein microarrays, thus allowing the differentiation of sera samples containing high level of anti-histone antibodies.

For all sera samples, an additional analysis was performed using the western blot technique, which is known to be sensitive for the detection of anti-histone antibodies (AHA) in serum $(26,27)$. The summary of the results obtained with the protein microarrays, ELISA, and western blot is presented in Table 2. For the eight tested sera samples, the data collected shows that concordant results between the protein microarrays and the western blot are found in $75 \%$ of the sera samples (sera P1, P4 - P8), while they are found in $50 \%$ of the samples between the protein microarrays and the ELISA (sera: P2, P6-P8). For the anti-histone $\mathrm{H} 1$ antibodies, concordant results between the western blot protein microarrays and the protein microarrays are found in $100 \%$ of the samples. For the anti-histone H3 antibodies, the P2 serum sample was tested negative with the western blot analysis, whereas it was tested positive with both ELISA and the MAMVE functionalized protein microarrays, and the P3 serum sample was tested positive only on the protein microarrays. This last point should be supported with additional samples, but it is important to note that the results obtained from the MAMVE functionalized protein microarrays are in agreement with one or both reference methods for the detection of anti-histone antibodies in the serum of SLE patients. 


\section{Conclusion}

Miniaturized immunoassays displaying a limit of detection 50 fold lower than traditional ELISA technique were developed on glass slides modified with a MAMVE copolymer. The optimal conditions for the chemical functionalization of the slides were found to be a $3 \mathrm{mg} / \mathrm{mL}$ concentration of MAMVE copolymer, and a concentration of $1 \mathrm{mg} / \mathrm{mL}$ of histone proteins. The density and spatial distribution of the grafted reactive groups (anhydride moieties) on the surface allow for the covalent immobilization of histone proteins which have retained their biological activity. Under these conditions, low abundant anti-histone antibodies present in a small volume of biological samples could be detected. Further analysis are in progress in order to evaluate the exact protein grafting density on the MAMVE functionalized surfaces by immobilizing fluorescent proteins as reference.

This novel surface chemistry was tested for the detection of anti-histone $\mathrm{H} 1$ and anti-histone $\mathrm{H} 3$ autoantibodies in SLE human sera, and the analytical performance was compared to standard immunoassays (ELISA and western-blot). Results indicate that our protein microarray is more sensitive than both standard immunoassays. Moreover, our surfaces compared favourably with some commercially available surfaces (16). In the future, this very promising result needs to be supported by testing a large number of sera samples of various concentrations, as well as other biological models.

Thus, immunoassays on MAMVE functionalized surfaces can be utilized to efficiently detect AHA in human sera samples. Recent studies suggest that over 100 autoantibodies may be present in SLE patients (28), indicating that the small spectrum of autoantibodies that are currently measured are not adequately assessing this complex disease. Therefore, the immobilization strategy developed 
herein may be particularly useful for the parallel screening of a broader range of autoantibodies which would have the potential to provide significantly novel insights into the diagnosis, pathogenesis and prognosis of patients with SLE and other autoimmune diseases $(6,29)$.

\section{Acknowledgments}

This work was supported by grants from Région Rhône-Alpes through its priority program "Sciences Analytiques Appliquées" and from the Centre National de la Recherche Scientifique (France) through its program «Protéomique et Génie des Protéines ». The authors are grateful to $\mathrm{Dr}$ Laura A. Rowe (Institute of Biotechnology, University of Cambridge, UK) for reading the manuscript.

\section{References}

[1] S. F. Kingsmore, Multiplexed protein measurement: technologies and applications of protein and antibody arrays., Nature Reviews Drug Discovery 5 (2006) 310-320.

[2] P. Angenendt, J. Glokler, D. Murphy, H. Lehrach, and D. J. Cahill, Toward optimized antibody microarrays: a comparison of current microarray support materials, Analytical Biochemistry 309 (2002) 253-260.

[3] B. B. Haab, M. J. Dunham, and P. Brown, Protein microarrays for highly parallel detection and quantitation of specific proteins and antibodies in complex solutions, Gennome Biology 2 (2001) research0004.1-0004.13.

[4] G. MacBeath, Protein microarrays and proteomics, Nature Genetics 32 (2002) 526-532. 
[5] W. H. Robinson, L. Steinman, and P. J. Utz, Protein and peptide array analysis of autoimmune disease, Biotechniques (2002) 66-69.

[6] W. H. Robinson, C. DiGennaro, W. Hueber, B. B. Haab, M. Kamachi, E. J. Dean, S. Fournel, D. Fong, M. C. Genovese, H. E. de Vegvar, K. Skriner, D. L. Hirschberg, R. I. Morris, S. Muller, G. J. Pruijn, W. J. van Venrooij, J. S. Smolen, P. O. Brown, L. Steinman, and P. J. Utz, Autoantigen microarrays for multiplex characterization of autoantibody responses, Nat Med 8 (2002) 295-301.

[7] Q.-Z. Li, J. Zhou, A. E. Wandstrat, F. Carr-Johnson, V. Branch, D. R. Karp, C. Mohan, E. K. Wakeland, and N. J. Olsen, Protein array autoantibody profiles for insights into systemic lupus erythematosus and incomplete lupus syndromes, Clinical and Experimental Immunology 147 (2006) 60-70.

[8] H. Zhu, and M. Snyder, Protein chip technology, Curr Opin Chem Biol 7 (2003) 55-63.

[9] S. L. Seurynck-Servoss, A. M. White, C. L. Baird, K. D. Rodland, and R. C. Zangar, Evaluation of surface chemistries for antibody microarrays, Analytical Biochemistry 371 (2007) 105-115.

[10] Q. Z. Li, C. Xie, T. Wu, M. Mackay, C. Aranow, C. Putterman, and C. Mohan, Identification of autoantibody clusters that best predict lupus disease activity using glomerular proteome arrays, J Clin Invest 115 (2005) 3428-39.

[11] W. Hueber, B. A. Kidd, B. H. Tomooka, B. J. Lee, B. Bruce, J. F. Fries, G. Sonderstrup, P. Monach, J. W. Drijfhout, W. J. van Venrooij, P. J. Utz, M. C. Genovese, and W. H. Robinson, Antigen microarray profiling of autoantibodies in rheumatoid arthritis, Arthritis Rheum 52 (2005) 2645-55. 
[12] F. J. Quintana, P. H. Hagedorn, G. Elizur, Y. Merbl, E. Domany, and I. R. Cohen, Functional immunomics: microarray analysis of $\lg G$ autoantibody repertoires predicts the future response of mice to induced diabetes, Proc Natl Acad Sci U S A 101 Suppl 2 (2004) 14615-21.

[13] A. Lueking, O. Huber, C. Wirths, K. Schulte, K. M. Stieler, U. Blume-Peytavi, A. Kowald, K. Hensel-Wiegel, R. Tauber, H. Lehrach, H. E. Meyer, and D. J. Cahill, Profiling of alopecia areata autoantigens based on protein microarray technology, Mol Cell Proteomics 4 (2005) 1382-90.

[14] S. Horn, A. Lueking, D. Murphy, A. Staudt, C. Gutjahr, K. Schulte, A. Konig, M. Landsberger, H. Lehrach, S. B. Felix, and D. J. Cahill, Profiling humoral autoimmune repertoire of dilated cardiomyopathy (DCM) patients and development of a diseaseassociated protein chip, Proteomics 6 (2006) 605-13.

[15] P. Angenendt, J. Glokler, J. Sobek, H. Lehrach, and D. J. Cahill, Next generation of protein microarray support materials: evaluation for protein and antibody microarray applications, J Chromatogr A 1009 (2003) 97-104.

[16] I. Balboni, C. Lim, J. D. Tenenbaum, and P. J. Utz, Evaluation of microarray surfaces and arraying parameters for autoantibody profiling, Proteomics 8 (2008) 3443-3449.

[17] S.-y. Seong, and C.-y. Choi, Current status of protein chip development in terms of fabrication and application, Proteomics 3 (2003) 2176-2189.

[18] V. Dugas, G. Depret, B. Chevalier, X. Nesme, and E. Souteyrand, Immobilization of single-stranded DNA fragments to solid surfaces and their 
repeatable specific hybridization: covalent binding or adsorption? Sensors and Actuators, B: Chemical 101 (2004) 112-121.

[19] G. El Khoury, E. Laurenceau, V. Dugas, Y. Chevolot, Y. Merieux, M.-C. Duclos, E. Souteyrand, D. Rigal, J. Wallach, and J.-P. Cloarec (2007) in 29th Annual International Conference of the IEEE Engineering in Medicine and Biology, Vol. 1, pp. 2242-2246, IEEE, Lyon.

[20] D. Saboulard, V. Dugas, J. Broutin, M. Jaber, E. Souteyrand, J. Sylvestre, and M. Delcourt, High-throughput site-directed mutagenesis using oligonucleotides synthesized on DNA-chips, BioTechniques 39 (2005) 363-368.

[21] L. Allard, V. Cheynet, G. Oriol, B. Mandrand, T. Delair, and F. Mallet, Versatile method for production and controlled polymer-immobilization of biologically active recombinant proteins, Biotechnology And Bioengineering 80 (2002) 341-348.

[22] K. Isosaki, N. Seno, I. Matsumoto, T. Koyama, and S. Moriguchi, Immobilization Of Protein Ligands With Methyl Vinyl Ether Maleic-Anhydride Copolymer, Journal Of Chromatography 597 (1992) 123-128.

[23] S. Soultani-Vigneron, V. Dugas, M. H. Rouillat, J. Fédollière, M. C. Duclos, E. Vnuk, M. Phaner-Goutorbe, V. Bulone, J. R. Martin, J. Wallach, and J. P. Cloarec, Immobilisation of oligopeptidic probes for microarray implementation: characterisation by FTIR, Atomic Force Microscopy and 2D fluorescence, Journal of Chromatography B 822 (2005) 304-310.

[24] P. Moncharmont, and P. Monneron, Essai d'un témoin multiparamétrique au laboratoire de qualification biologique du don, Revue Française des Laboratoires 1998 (1998) 45-47. 
[25] R. R. Sokal, and J. F. Rolhf, Biometry: the principles and practice of statistics in biological research, W H Freeman \& Co, New York, 1981.

[26] W. Egner, The use of laboratory tests in the diagnosis of SLE, Journal Of Clinical Pathology 53 (2000) 424-432.

[27] I. Ghedira, H. Landolsi, A. Mankai, N. Fabien, and M. Jeddi, Antihistones antibodies in systemic lupus erythematosus, comparison of three assays: Elisa, dot blot and immunoblot, Pathologie Biologie 54 (2006) 148-154.

[28] Y. Sherer, A. Gorstein, M. J. Fritzler, and Y. Shoenfeld, Autoantibody explosion in systemic lupus erythematosus: more than 100 different antibodies found in SLE patients, Semin Arthritis Rheum 34 (2004) 501-37.

[29] W. Hueber, P. J. Utz, L. Steinman, and W. H. Robinson, Autoantibody profiling for the study and treatment of autoimmune disease, Arthritis Res 4 (2002) 290-5. 


\section{Figures captions}

Figure 1. Covalent immobilization of histone proteins $(\mathrm{H} 1$ or $\mathrm{H} 3)$ on NHS ester $(\mathrm{A})$ and MAMVE copolymer (B) functionalized glass slides.

Figure 2. Validation of the histone $\mathrm{H} 3$ / anti-histone $\mathrm{H} 3$ model and the determination of the low limit of detection of anti-histone H3 polyclonal antibody by ELISA technique and immunoassays on NHS ester functionalized surfaces. Thresholds were calculated from the mean of OD $(492 \mathrm{~nm})$ or fluorescence intensity values of the dilution buffer.

A) ELISA technique: Histone $\mathrm{H} 3$ was coated at $5 \mu \mathrm{g} / \mathrm{mL}\left(3.5 \times 10^{-11} \mathrm{~mol} ; 100 \mu \mathrm{L}\right)$ and $10 \mu \mathrm{g} / \mathrm{mL}\left(7 \times 10^{-11} \mathrm{~mol} ; 100 \mu \mathrm{L}\right)$. OD values were measured at $492 \mathrm{~nm}$ versus the dilution factor of rabbit anti-histone $\mathrm{H} 3$ antibody $\left(10^{-8}\right.$ to $\left.10^{-2}\right)$..

B) Immunoassays on NHS ester functionalized surfaces: Immobilization of histone $\mathrm{H} 3$ at $0.5 \mathrm{mg} / \mathrm{mL}\left(3.5 \times 10^{-11} \mathrm{~mol}\right)$ and $1 \mathrm{mg} / \mathrm{mL}\left(7 \times 10^{-11} \mathrm{~mol}\right)$. The mean of the fluorescence intensity was measured at $532 \mathrm{~nm}$ versus the dilution factor of rabbit anti-H3 antibody $\left(10^{-8}\right.$ to $\left.10^{-2}\right)$.

Figure 3. Effect of MAMVE concentration on the detection of anti-histone $\mathrm{H} 3$ antibodies on glass slides. Histone $\mathrm{H} 3$ protein was covalently immobilized at 0.5 and $1 \mathrm{mg} / \mathrm{mL}$.

Figure 4. Panel A: Image of the miniaturized immunoassays on the MAMVE functionalized glass slide for the detection of anti-histone $\mathrm{H} 1$ and anti-histone $\mathrm{H} 3$ antibodies from human sera samples. Image analysis was performed with GenePix Pro 6.0 software.

Panel B: Array layout used for the miniaturized immunoassays from SLE patient sera (P1 to P8: rounds with small dots), healthy donor sera (S1 to S6: white rounds) and buffer B (PBS-BSA 1\%: gray rounds) as negative control for secondary antibody 
non-specific adsorption. Each serum was tested in duplicate on each slide. Lanes 1 and 2 were not functionalized with histone proteins (non-specific adsorption of antibodies). Lanes 3 and 4 were functionalized with histone $\mathrm{H} 1$ at $1 \mathrm{mg} / \mathrm{mL}$. Lanes 6 and 7 were functionalized with histone $\mathrm{H} 3$ at $1 \mathrm{mg} / \mathrm{mL}$. Detection of human antibodies was performed with goat anti-human IgG antibody fluorescently labelled with Cy3.

Figure 5. Comparison between MAMVE functionalized protein microarrays and ELISA for the detection of anti-histone $\mathrm{H} 1$ and $\mathrm{H} 3$ antibodies in human sera samples, expressed in the ratio = signal value/cutoff.

(Cutoff $=1$ a.u $=$ mean of negative control signals $+t_{0.01} \mathrm{SD} \sqrt{ }(\mathrm{n}+1 / \mathrm{n})$; $t$ : Student's $t$ distribution for $\alpha=0.01$, with $\mathrm{n}-1$ degree of freedom; $\mathrm{n}=6$ negative control sera). 
Development of miniaturized immunoassay: influence of surface chemistry and comparison with ELISA and Westernblot

Short title: Surface chemistry for protein microarrays

Subject category: Immunoassays that introduce a unique approach

Graziella El Khoury ${ }^{1}$, Emmanuelle Laurenceau ${ }^{1}$, Yann Chevolot ${ }^{1}$, Yves Mérieux ${ }^{2}$, Agnès Desbos ${ }^{3}$, Nicole Fabien ${ }^{3}$, Dominique Rigal ${ }^{2}$, Eliane Souteyrand ${ }^{1}$, Jean Pierre Cloarec ${ }^{1}$

${ }^{1}$ Université de Lyon, Institut des Nanotechnologies de Lyon - INL, UMR CNRS 5270, site Ecole Centrale de Lyon, 36, Avenue Guy de Collongue, Ecully, France

2 Etablissement Français du Sang - EFS - Lyon, 1-3, Rue du Vercors, 69007 Lyon France

${ }^{3}$ Laboratoire d'Auto-Immunité, Hôpital Lyon-Sud, Hospices Civils de Lyon, 69495 Pierre-Bénite, France

Corresponding Author*: Emmanuelle Laurenceau, Université de Lyon, Institut des Nanotechnologies de Lyon - INL, UMR CNRS 5270, 36, Avenue Guy de Collongue, Ecully, France.

Tel +33 (0)4 72186240

Fax : +33 (0)4 78433593

E-mail Adresse: emmanuelle.laurenceau@ec-Iyon.fr

* to Whom proof should be sended 


\section{Abstract}

Protein microarray technology provides a useful approach for the simultaneous serodetection of various antibodies in low sample volumes. In order to implement functional protein microarrays, appropriate surface chemistry has to be designed so that both the protein structure and the biological activity can be retained. In the present study, two surface chemistries for protein microarrays and immunofluorescent assays have been developed. Glass slides were functionalized with NHS-ester via a monofunctional silane or Maleic Anhydride-alt-Methyl Vinyl Ether (MAMVE) copolymer to allow covalent grafting of histone proteins. Analytical performance of these microarrays were then evaluated for the detection of antihistone autoantibodies present in the sera of patients suffering from a systemic autoimmune disease, i.e. systemic lupus erythematosus (SLE), and the results compared with classical immunoassays, ELISA and western blot. The detection limit of our MAMVE copolymer microarrays was 50 fold lower than the detection limit of the classical ELISA. Furthermore, 100 fold less volume of biological samples was required with these miniaturized immunoassays.

Keywords: Protein microarrays; Autoimmune diseases; MAMVE copolymer ; Surface chemistry ; Protein immobilization 


\section{Introduction}

The detection of single proteins in complex biological solutions (e.g. sera) is usually performed using immunoassays. The most widely used format is ELISA, which has several benefits, such as reproducibility (coefficient of variation between $5-20 \%$ ), sensitivity (dynamic range of 3 logs), a low detection limit (around $1 \mathrm{pg} / \mathrm{mL}$ ) and ease of use (1). However, the standard 96-well plate ELISA has a limited ability to efficiently screen large numbers of proteins, particularly when sample volumes are limited. In addition, proteins are immobilized on a solid support by physical adsorption (non-covalent binding) in ELISA, leading to a low surface density and a partial lost of biological activity due to protein denaturation $(2,3)$. The methods used in protein microarray technology should overcome some of these limitations $(3,4)$. Protein microarrays allow for the high-throughput and parallel screening of various biological interactions with tiny volumes of sample and reagents. Therefore, multiplexed and miniaturized immunoassays have the potential to become a powerful tool for the screening and validation of biomarkers in complex diseases such as cancer and autoimmune disease $(5,6)$.

During the diagnosis of autoimmune diseases, such as systemic lupus erythematosus (SLE) or arthritis rheumatoid, autoantibodies are frequently directed against certain cytoplasmic or nuclear antigens of the cell (double and single stranded DNA, histones, ribonucleoproteins, etc.). Previously, proteins such as histones, ribonucleoproteins and other biomolecules (peptides, DNA, etc.) have been immobilized by physical adsorption onto poly-L-Lysine or nitrocellulose-coated (FAST slide) glass slides. These microarrays were then used for the detection of autoantibodies in the serum of patients with various autoimmune diseases $(6,7)$. 
Autoantigen microarrays are ideally suited to autoantibody profiling in complex solution like serum, within a single experiment.

A crucial parameter in the development of protein microarrays is the design of well defined surface chemistry, which allows the biological activity of proteins to be retained when immobilized on solid supports (e.g. membranes, glass slides). A large variety of surface modifications and chemistries have been employed to immobilize proteins onto glass slides (8), and ideally these immobilization schemes must have high binding capacity, an ability to retain protein activity, a low variability between slides and a high signal-to-noise for detection (9). These previous studies were performed on commercially available slide surfaces such as poly-L-lysine $(10,11)$, SuperEpoxy $(11,12)$, SuperAldehyde (10), Hydrogel (10), Full Moon and FAST® slides $(7,13,14)$, as well as on "home-made" modifications such as silanized, PEGEpoxy and dendrimer slides (15). Seurynk-Servoss et al. have tested the immobilization of 23 antibodies on 17 commercially available modified glass sides. They studied the morphology of spots, slide and spot background noise, limit of detection (LOD) and reproducibility. Their results show that all these parameters varied with the surface chemistry. For example, the LOD varied from 0.1 to 475 $\mathrm{pg} / \mathrm{mL}$ and the coefficients of variation ranged from 16 to $40 \%$. So the activity of the immobilized antibodies and the quality of the produced data were affected by the surface properties. According to their results, aldehyde-silane, poly-L-lysine or aminosilane modified glass slide give superior results in sandwich ELISA microarray (9). In another study, Balboni et al. have evaluated performances of 24 surfaces with about 50 autoantigens. They also found that the quality of the data is dependent on surface chemistry (16). 
The oriented immobilization of proteins can be performed by using affinity tags, such as for example His, GST or biotin tag on Ni-NTA (Ni-nitrilotriacetic acid), gluthatione or avidin modified slides, respectively (for review see (17)).

Therefore, it is very important to adapt the surface chemistry of the slide in a microarray to the nature of the protein to be immobilized. The present work consists of exploring two surface chemistries in order to functionalize glass slides for the covalent immobilization of histone proteins:

- N-hydroxysuccinimide (NHS) ester surface via a monofunctional silane. Monofunctional silane cannot self polymerize (18). The resulting modified surface is robust (can withstand on-chip peptide and DNA synthesis), non damaged under stringency washings and reproducible $(19,20)$

- aminated surface modified with Maleic Anhydride-alt-Methyl Vinyl Ether (MAMVE) copolymer. MAMVE copolymer presents anhydride moieties which highly react towards primary amino groups. The copolymer has been previously used for the modification of biomolecules (e.g. peptides, proteins) in various applications, such as the immobilization of bioconjugates on ELISA microtiter plates $(21,22)$. However, in these previous studies the bioconjugates were immobilized by physical adsorption onto the polystyrene surfaces.

The performance of the protein microarrays developed herein was evaluated for the detection of anti-histone antibodies in human sera of patients with SLE, and the analytical performances of these miniaturized immunoassays was then compared to those of classical ELISA and western blot on patient sera.

\section{Materials and methods}




\subsection{Reagents and biomolecules}

Histone proteins from calf thymus [H1 (type III-S), H3 (type VIII-S) and unfractionated whole histone (type II-A)]; BSA lyophilized powder, 4-chloro-1-naphtol (30 mg tablets) DMSO anhydrous, $\geq 99.9 \%$, and $0.01 \mathrm{M} \mathrm{PBS,} \mathrm{pH} 7.4$ at $25^{\circ} \mathrm{C}$ ( $0.0027 \mathrm{M}$ potassium chloride and $0.138 \mathrm{M}$ sodium chloride) were all supplied from Sigma-Aldrich (St. Quentin Fallavier, France).

SDS, sodium bicarbonate $\mathrm{NaHCO}_{3}\left(\mathrm{M}_{\mathrm{r}} 84.01 \mathrm{~g} / \mathrm{mol}\right)$, sodium carbonate $\mathrm{Na}_{2} \mathrm{CO}_{3}\left(\mathrm{M}_{\mathrm{r}}\right.$ $105.99 \mathrm{~g} / \mathrm{mol}), \quad \mathrm{N}$-hydroxysuccinimide (NHS), N,N'-diisopropylcarbodiimide, tetrahydrofuran (THF), purum grade, were obtained from Fluka (St. Quentin Fallavier, France).

Tween $^{\circledR} 20$ was purchased from Roth-Sochiel (Lauterbourg, France). Ortho-phenylenediamine (OPD, 2 mg tablets) was purchased from BD Biosciences Pharmingen (Le Pont-de-Claix, France). Hydrogen peroxide $\left(\mathrm{H}_{2} \mathrm{O}_{2}\right)$ solution 30 Volume was obtained from Gilbert laboratories (Hérouville Saint - Claire, France). Maleic anhydride-alt-methyl vinyl ether copolymer [P (MAMVE); $M_{r} 67000 \mathrm{~g} / \mathrm{mol}$ ] was provided by Biomérieux - CNRS - UMR 2714 (Ecole Normale Supérieure, Lyon, France).

Ultrapure water (18.2 M $\Omega$ ) was delivered by an Elga water system.

Rabbit anti-histone $\mathrm{H} 3$ antibody (IgG fraction of antiserum, buffered aqueous solution) was purchased from Sigma-Aldrich. Cy3 goat anti-rabbit $\lg G[H+L]$ (2 mg/mL) and Cy3 goat anti-human IgG [H $+\mathrm{L}](2 \mathrm{mg} / \mathrm{mL})$, Horseradish Peroxidase (HRP) goat anti-rabbit $\lg G[\mathrm{H}+\mathrm{L}](2 \mathrm{mg} / \mathrm{mL})$ and HRP goat anti-human $\lg G[\mathrm{H}+\mathrm{L}]$ (2 mg/mL) were all purchased from Interchim (Montlucon, France). 40\% acrylamidebis acrylamide solution (37.5:1) was supplied from Bio-Rad. 
Microscope borosilicate flat glass slides $(76 \times 26 \times 1 \mathrm{~mm})$ were obtained from Schott (Mainz, Germany). Microwell plates, Nunc MaxiSorp (96 wells, flat bottom) were supplied from Nunc (distributed by VWR). Nitrocellulose membranes $(0.2 \mu \mathrm{m})$ were supplied from Bio-Rad (Marnes-la-Coquette, France).

\subsection{Buffers}

$0.01 \mathrm{M}$ of PBS or PBS (1X) was prepared by dissolving the content of one pouch of dried powder in $1 \mathrm{~L}$ of ultrapure water.

$0.05 \mathrm{M}$ and $0.02 \mathrm{M}$ sodium carbonate buffers $\left(\mathrm{NaHCO}_{3} / \mathrm{Na}_{2} \mathrm{CO}_{3}\right), \mathrm{pH} 9.6$ and $\mathrm{pH}$ 10.7, respectively, were prepared from $0.1 \mathrm{M} \mathrm{NaHCO}_{3}$ and $0.1 \mathrm{M} \mathrm{Na}_{2} \mathrm{CO}_{3}$ solutions in ultrapure water.

Blocking solution was prepared by dissolving $2 \mathrm{~g}$ of BSA in $100 \mathrm{~mL}$ PBS buffer. Washing buffer was $0.01 \mathrm{M}$ PBS, $0.05 \%$ Tween $^{\circledR} 20$ (PBS-T), pH 7.4.

\subsection{Serum samples}

Eight sera of SLE patients were obtained from a sera collection (Centre de Ressources Biologiques, CRB Immunobiothèque) that was approved by the Institutional Review Board of the Hospices Civils de Lyon. Written informed consent was obtained from all patients. Six sera from healthy donors were kindly provided by Etablissement Français du Sang (Lyon, France). All sera were stored at $-80^{\circ} \mathrm{C}$.

\subsection{Western blot technique}

Unfractionated whole histone (20 $\mu \mathrm{g} / \mathrm{lane})$ was run on SDS-PAGE (15\% polyacrylamide gel) at $200 \mathrm{~V}$ for $50 \mathrm{~min}$, and the resolved proteins were transferred to nitrocellulose membranes. The sheets were soaked with $1 \%$ non-fat milk PBS-T (30 min, at room temperature) to block the free protein binding sites. The 
nitrocellulose strips were then incubated $(90 \mathrm{~min})$ with the human sera (dilution 1:100).

The antigen-antibody complexes were probed with HRP-conjugated anti-human IgG (dilution 1:400) and revealed with the peroxydase substrate (4-chloro-1-naphtol $0.06 \%(\mathrm{w} / \mathrm{v}) ; \mathrm{H}_{2} \mathrm{O}_{2} 0.033 \%(\mathrm{v} / \mathrm{v})$ ), for $20 \mathrm{~min}$ in the dark, at room temperature.

\subsection{ELISA technique}

The ELISA microplate was coated overnight at $4^{\circ} \mathrm{C}$ with either $100 \mu \mathrm{L}$ of histone $\mathrm{H} 1$ or histone $\mathrm{H} 3$ solution at $5 \mu \mathrm{g} / \mathrm{mL}$ or $10 \mu \mathrm{g} / \mathrm{mL}$ in $0.1 \mathrm{~N}$ carbonate buffer, $\mathrm{pH}$ 9.6. After discarding the antigen solution, the microplate was washed three times with $200 \mu \mathrm{L}$ of PBS-T buffer and incubated with $200 \mu \mathrm{L}$ of blocking solution for $2 \mathrm{hrs}$ at $37^{\circ} \mathrm{C}$. After washing with PBS-T buffer, wells were incubated for $1 \mathrm{hr}$ at $37^{\circ} \mathrm{C}$ with $100 \mu \mathrm{L}$ of polyclonal anti-histone $\mathrm{H} 3$ antibody at different dilutions $\left(1: 10^{8}\right.$ to $\left.1: 10^{2}\right)$ in a $1 \%$ BSA/PBS-T solution. The microplate was then washed three times with $200 \mu \mathrm{L}$ of PBS-T buffer and incubated with $100 \mu \mathrm{L}$ of HRP goat anti-rabbit IgG diluted at $1: 10^{4}$, for $1 \mathrm{hr}$ at $37^{\circ} \mathrm{C}$, then washed six times with $200 \mu \mathrm{L}$ of PBS-T buffer. A volume of $100 \mu \mathrm{L}$ of OPD solution was added and the microplate was incubated for $20 \mathrm{~min}$ in the dark at room temperature. The reaction was stopped by adding $100 \mu \mathrm{L}$ of $1 \mathrm{~N}$ $\mathrm{H}_{2} \mathrm{SO}_{4}$ solution. Optical densities (OD) were read at $492 \mathrm{~nm}$ with an ELISA microplate reader (Metertech $\Sigma 960$ ).

Human sera tested in ELISA were diluted at $1: 10^{2}$ in $1 \%$ BSA/PBS-T solution.

\subsection{Chemical functionalization of glass slides}

Glass slides (borosilicate, Schott) were functionalized according to previous protocols $(18,23)$. In brief, the supports were silanized with tert-butyl-11- 
(dimethylamino)silylundecanoate. Terbutyl esters were then hydrolyzed with formic acid $7 \mathrm{~h}$ at room temperature. The slides were washed with dichloromethane for $10 \mathrm{~min}$ in ultrasonic bath, followed by $10 \mathrm{~min}$ in deionized water (enough volume was added to completely immerse the slides). Activation of carboxylic acid was carried out with a mixture of NHS/DIC (molar ratio of 1:1, $0.1 \mathrm{M}$ ) in THF, overnight at room temperature, washed $10 \mathrm{~min}$ in tetrahydrofuran and $10 \mathrm{~min}$ in dichloromethane, under sonication, to obtain NHS activated esters.

The slides were incubated in a $0.1 \mathrm{M}$ solution of aminated Jeffamine D-230 (polyoxypropylenediamine) linker, overnight at room temperature. The surfaces were then washed for $30 \mathrm{~min}$ with $0.1 \% \mathrm{SDS}$ at $70^{\circ} \mathrm{C}$ and rinsed with ultrapure water.

The generated amino modified surfaces are then incubated in $0.02 \mathrm{M}$ sodium carbonate solution, $\mathrm{pH} 10.7$, for $1 \mathrm{hr}$, at room temperature to deprotonate amine functions. Slides were then dried by centrifugation for $3 \mathrm{~min}$ at $1300 \mathrm{rpm}$, and washed in DMSO for 10 min under sonication, at room temperature. Then, they were incubated in MAMVE solutions in DMSO at different concentrations $(1,3$ and $5 \mathrm{mg} / \mathrm{mL}$ ), overnight at room temperature. Finally, the slides were washed with PBS $1 \mathrm{X}$ and dried by centrifugation.

\subsection{Immunoassays on protein microarrays}

Protein solutions of histone $\mathrm{H} 1$ or $\mathrm{H} 3$ were prepared in PBS $1 \mathrm{X}$ at two different concentrations ( 0.5 and $1 \mathrm{mg} / \mathrm{mL})$. A volume of $1 \mu \mathrm{L}$ of each solution, as well as of the dilution buffer (PBS 1X) for a negative control, was manually spotted onto NHS esters (Figure 1.A) or MAMVE modified glass slides (Figure 1.B). Spot diameter was approximately $2 \mathrm{~mm}$. Protein solutions were allowed to react overnight at room temperature on NHS ester slides, and for $3 \mathrm{hrs}$ at $37^{\circ} \mathrm{C}$ on MAMVE slides in a water 
saturated atmosphere. These reaction conditions are typical for protein-MAMVE copolymer coupling (21). The slides were then washed and sonicated $1 \times 3$ min with PBS-T, 1 min with ultrapure water and dried by centrifugation for 3 min at $1300 \mathrm{rpm}$. The slides were blocked with $2 \%$ BSA / PBS solution and left to incubate $2 \mathrm{~h}$ at $37^{\circ} \mathrm{C}$, then washed and sonicated with PBS-T, ultrapure water and dried by centrifugation. Spots were then incubated with $1 \mu \mathrm{L}$ of either rabbit anti-histone $\mathrm{H} 3$ purified polyclonal antibody (dilution between $1: 10^{8}$ and $1: 10^{4}$ in PBS-T / 1\% BSA solution) or human sera diluted at $1: 10^{2}$. The slides were left to react for $1 \mathrm{hr}$ at $37^{\circ} \mathrm{C}$ in water saturated atmosphere, then thoroughly rinsed with water, washed and sonicated for $3 \times 3$ min with PBS-T, 1 min with water and dried by centrifugation. Spots were then incubated with either Сy3 goat anti-rabbit IgG or Сy3 anti-human IgG, diluted at $1: 10^{2}$ in PBS-T, for $1 \mathrm{hr}$ at $37^{\circ} \mathrm{C}$, in water saturated atmosphere. The slides were washed $6 \times 2$ min with PBS-T, 1 min with water under sonication and dried by centrifugation for $3 \mathrm{~min}$ at $1300 \mathrm{rpm}$.

\subsection{Fluorescence scanning and image analysis}

Slides were scanned with GenePix ${ }^{\circledR}$ Personal $4100 A$ microarray scanner (Axon Instruments / Molecular Devices, Union City, USA) at a spatial resolution of $20 \mu \mathrm{m}$ pixel and a PhotoMultiplier Tube (PMT) gain of 500. Excitation and emission wavelengths were $532 \mathrm{~nm}$ and $570 \mathrm{~nm}$ respectively, corresponding to Cy3 molecule. Images were analyzed with GenePix Pro 6.0 software. The complete data set analyzed consisted of the average pixel fluorescence intensities of spots. Each measurement point presented in this article corresponds to the average of four independent experiments performed in duplicate. 


\subsection{Statistical analysis}

Performances of ELISA and protein microarrays were compared in term of reproducibility, repeatability, low detection limit, dynamic range and sensitivity.

Repeatability and reproducibility were evaluated in percentile as the coefficients of variation (CV) intra- and inter-assay, respectively:

$\% \mathrm{CV}=(\mathrm{SD} / \mathrm{Mean}) \times 100$.

CV intra- and inter-assay were considered as acceptable for values lower then $8 \%$ and $15 \%$, respectively (24).

The threshold value for the determination of low limit of detection was calculated from the mean of signal values (OD or fluorescence intensity) of negative controls (spots or wells of dilution buffer). Threshold of positivity (cut-off) for immunoassays performed with human sera was calculated from the mean of negative sera values of healthy donors (25).

Threshold or cut-off $=$ Mean $+t_{0.01} S D \sqrt{ }(n+1 / n)$

Thresholds were calculated with $99 \%$ confidence interval around the mean $(\alpha=0.01$ in Student's t-distribution for $\mathrm{n}-1$ degree of freedom); $\mathrm{n}$ : number of test points or negative controls.

In order to compare the results obtained with ELISA and protein microarrays, a ratio was calculated for each serum sample: Ratio = Mean / Cut-off. The mean was also calculated from OD or fluorescence intensities of negative sera (25). A serum sample was considered as positive if the corresponding ratio was higher than 1 .

The dynamic range corresponded to the ratio of high detection limit over low detection limit of each immunoassay. The sensitivity is given by the slope of the curve $[O D$ or fluorescence intensity $=f$ (dilution factor)] in the linear zone. 


\section{Results and discussion}

\subsection{Optimization of protein immobilization conditions onto functionalized glass}

slides

Performance (limit of detection, reproducibility, etc.) of ester activated and MAMVE functionalized glass slides were first evaluated for the biological activity of immobilized histone proteins versus anti-histone antibodies, and compared to the performances of a classical ELISA also used for detection of these proteins.

\subsubsection{ELISA}

The biological model chosen in this study was first validated and characterized with classical ELISA technique. For this purpose, biological interaction of anti-histone $\mathrm{H} 3$ antibody was evaluated with either histone $\mathrm{H} 1$ or $\mathrm{H} 3$. Histone $\mathrm{H} 1$ served as a negative control to test the specificity of anti-histone $\mathrm{H} 3$ antibody for histone $\mathrm{H} 3$. Histone $\mathrm{H} 1$ and $\mathrm{H} 3$ proteins were adsorbed at $5 \mu \mathrm{g} / \mathrm{mL}$ and $10 \mu \mathrm{g} / \mathrm{mL}$ in microplate wells, and dilutions of rabbit $\lg G$ polyclonal antibody ranging from $10^{-8}$ to $10^{-2}$ were added. Results obtained after revelation with HRP anti-rabbit IgG secondary antibody are presented in Figure 2.A.

As expected, anti-H3 antibody interacts specifically with histone $\mathrm{H} 3$ in a dosedependent way for dilution factors of anti-H3 antibody lower than $10^{-3}$. No interaction with histone $\mathrm{H} 1$ is detected in the dilution range tested. Very low non-specific adsorption of antibodies is observed on the microplate surface as indicated by the low OD values ( 0.01 a.u) obtained for wells tested with the dilution buffer. In addition, according to the calculated CV values of intra- and inter-assays $(7.3 \pm 0.6$ $\%$ and $11 \pm 2 \%$, respectively) we notice a good reproducibility of the ELISA technique. Moreover, as shown in Figure 2.A, the lower limit of detection (LOD) of 
histone $\mathrm{H} 3$ is reached for the antibody dilution factor at $10^{-6}$. The dynamic range of the assays ranges from 100 to 300 , as described in the literature. The sensitivity of the assays is similar for protein concentrations and is $0.4 \mathrm{a} . \mathrm{u} / \mathrm{unit}$ of dilution factor. Based on these results, histone proteins were immobilized at $5 \mu \mathrm{g} / \mathrm{mL}$ in subsequent ELISA tests.

\subsubsection{Immunoassays on NHS ester functionalized surfaces}

The ester activated groups on the modified slides allowed for the immobilization of proteins by covalent coupling through their primary amine functional groups ( $\mathrm{N}$-terminal end and amine function of the lysine side chain residues). In order to evaluate the sensitivity and the specificity of the immunoassay on NHS ester functionalized surfaces, immunoassays were performed with the same amount of proteins as in ELISA. Histone $\mathrm{H} 1$ and $\mathrm{H} 3$ were covalently immobilized at $0.5 \mathrm{mg} / \mathrm{mL}$ and $1 \mathrm{mg} / \mathrm{mL}$ on NHS ester functionalized surface (required volume was $1 \mu \mathrm{L}$ versus $100 \mu \mathrm{L}$ in ELISA) and an anti-histone $\mathrm{H} 3$ antibody dilution ranging from $10^{-8}$ to $10^{-2}$ was tested. Results displayed as the mean of fluorescence intensity versus the primary antibody dilution are shown in Figure 2.B. The fluorescence intensity increased with histone $\mathrm{H} 3$ and anti-histone $\mathrm{H} 3$ antibody concentrations, indicating the specificity and dose-dependent interaction between the antigen and its antibody. The signals relative to non-specific adsorption and interaction between histone $\mathrm{H} 1$ and anti-H3 antibody were not significant. The LOD of histone $\mathrm{H} 3$ was reached for the antibody dilution factors of $3 \times 10^{-6}$ for both protein concentrations. The dynamic range corresponding to the ratio of high detection limit over low detection limit was 333. 


\subsubsection{Immunoassays on MAMVE functionalized surfaces}

Surface modification with MAMVE copolymer was achieved through covalent coupling between the anhydride moieties of the copolymer and the amine groups of the slides. Proteins can then be immobilized on the functionalized surface through their primary amine functional groups ( $\mathrm{N}$-terminal end and amine function of lysine residues side chains), by reacting with the remaining anhydride moieties of the copolymer (Figure 1.B).

In order to develop immunoassays on MAMVE functionalized surfaces, the immobilization concentration of the copolymer on aminated slides had to be optimized. Taking into account previous results (data not shown), three concentrations of MAMVE (1, 3 and $5 \mathrm{mg} / \mathrm{mL})$ were tested with two concentrations of histone $\mathrm{H} 3$ protein $(0.5$ and $1 \mathrm{mg} / \mathrm{mL})$, corresponding to the same amount of protein used in ELISA, and anti-histone $\mathrm{H} 3$ antibody dilutions between $10^{-8}$ and $10^{-4}$. Results are reported on Figure 3. Regardless of the copolymer concentration, a very low non-specific adsorption was measured, as can be seen with the dilution buffer samples; threshold values are comparable $\left(7.6 \times 10^{5}\right.$ a.u). Comparison of the graphs indicates that the fluorescence signals, which are proportional to the biological interaction between the anti-histone $\mathrm{H} 3$ antibody and the histone $\mathrm{H} 3$, vary according to protein and MAMVE concentrations. For slides substituted with MAMVE at $1 \mathrm{mg} / \mathrm{mL}$, results are not significantly different for both histone $\mathrm{H} 3$ concentrations tested. However, more significant variation in the fluorescence signal was observed between both protein concentrations with $3 \mathrm{mg} / \mathrm{mL}$ of MAMVE than with $5 \mathrm{mg} / \mathrm{mL}$ of MAMVE, for the different dilutions of anti-histone $\mathrm{H} 3$ antibody.

Regardless of the polymer and histone concentrations, the dynamic range displayed the same value of 100 corresponding to 2 log scale. But the low limit of detection and 
the sensitivity of the immunoassay depended on the copolymer concentration, indicating that it is an important parameter which affects the performance of the test. Indeed, the reactive moieties of MAMVE copolymer are involved in both substitution on aminated glass slides, and in the covalent coupling with the amino groups of proteins. Their density and spatial distribution, related to polymer concentration, will thus determine the number and the orientation of coupled proteins, and therefore their biological activity. It is likely that the number of coupled proteins and/or the number of coupling sites per protein increase with polymer concentration. During protein immobilization, coupling reactions compete with the hydrolysis of anhydride moieties caused by aqueous conditions (PBS buffer). This hydrolysis reduces the amount of MAMVE reactive groups available for covalent coupling, and generates carboxylate groups. These carboxylate groups increase the solubility of the polymer in aqueous solutions which means that the proteins coupled to the polymer chains can remain in solution rather than close to the surface. This could be one of the reasons why the chemical functionalization with MAMVE copolymer lead improved the low limit of detection of the immunoassay by a factor of 150 compared to the NHS ester functionalized surfaces. The best performances in terms of the LOD $(2 \mathrm{x}$ $10^{-8}$ ) and sensitivity (0.3 a.u./ unit of dilution factor) were obtained for proteins immobilized at a $1 \mathrm{mg} / \mathrm{mL}$ concentration on a glass slide substituted with a $3 \mathrm{mg} / \mathrm{mL}$ concentration of MAMVE copolymer. With a lower concentration in MAMVE copolymer, i.e. $1 \mathrm{mg} / \mathrm{mL}$, the sensitivity of the assay was decreased, suggesting that the decreased density and the spatial distribution of reactive moieties on the copolymer do not permit efficient protein grafting on the surface. On the contrary, a higher concentration in MAMVE copolymer, i.e. $5 \mathrm{mg} / \mathrm{mL}$, reduced the LOD. This result could suggest that a high density of reactive groups on the copolymer can lead 
to the immobilization of the proteins through multiple sites of attachment, thereby decreasing the grafting density of functional immobilized histones, and their biological interactions with the antibodies.

\subsubsection{Comparison of immunoassays performances}

In Table 1, the analytical performances of the standard ELISA are compared with the immunoassays performed on NHS ester and MAMVE modified glass slides for the same amount of deposited histone $\mathrm{H} 3$ per test point: $7 \times 10^{-11}$ mol. For the three assays, coefficients of variation inter-assay are in the same range, indicating that these techniques display comparable and acceptable reproducibility. However, the ELISA technique seems to be slightly better in term of repeatability as indicated by the coefficient of variation intra-assay $(7.3+0.6 \%)$, compared to the NHS ester $(9.7+0.9 \%)$ and MAMVE modified surfaces $(9.4+2.6 \%)$.

Moreover, our surfaces compared favourably with some commercially available surfaces. Indeed, Balboni et al. (16) have tested 24 different surfaces for the immobilisation of nearly 50 autoantigens including histones $\mathrm{H} 3$ and $\mathrm{H} 1$, and tested their biological activity towards monoclonal antibodies and human sera. Among these surfaces, only three exhibited good spot morphology, reproducibility (interslide CV), repeatability (intraslide CV), low non-specific adsorption and limit of detection (LOD). Two surfaces were nitrocellulose-based surfaces (FAST and PATH) allowing physical adsorption of proteins. The third surface was functionalized with epoxy groups (SuperEpoxy2) allowing covalent grafting of proteins via their amino groups. Analyses performed with monoclonal antibodies indicate intraslide $\mathrm{CV}$ ranging from $7.6 \%$ (FAST) to $9 \%$ (SuperEpoxy2), and interslide CV ranging from $10.5 \%$ (FAST) to $17.8 \%$ (PATH). Both the NHS-ester and the MAMVE surfaces developed in this 
study allowed covalent grafting of proteins via their amino groups and exhibit intraslide and interslide CV of $9-10 \%$ and $11-12 \%$ respectively. However, it should be noted that our study was performed with polyclonal antibodies instead of monoclonal antibodies.

In terms of limit of detection, the MAMVE functionalized surface exhibited a LOD of 2 $\times 10^{-8}$ which was 50 fold lower than ELISA $\left(10^{-6}\right)$, and 150 fold lower than the NHS ester functionalized surface $\left(3 \times 10^{-6}\right)$. Thus, we can reach a LOD ranging from 1:300000 for the NHS-ester surface to 1:50000000 for the MAMVE surface with antiH3 polyclonal antibody. As a comparison, Balboni et al. (16) reached LOD ranging from 0.1 to $475 \mathrm{pg} / \mathrm{mL}$ with monoclonal antibodies. Concerning the dynamic range and the sensitivity of immunoassays, ELISA, NHS ester and MAMVE surfaces displayed similar performances. However, the analyte volume required for each spot on miniaturized immunoassays $(1 \mu \mathrm{L})$ was 100 fold lower than that required for ELISA 96 wells microplate $(100 \mu \mathrm{L})$.

On the basis of these results, we can conclude that the immunoassays performed on the MAMVE functionalized surface significantly improved the performance of the immunoassay especially, in term of the detection limit. Therefore, this novel surface chemistry was next used for the detection of $\lg G$ anti-histone autoantibodies directed against $\mathrm{H} 1$ and $\mathrm{H} 3$ histone classes in the sera of patients with SLE.

\subsection{Evaluation of the performance of MAMVE functionalized protein} microarrays for patient sera analysis: comparison with ELISA and western blot Eight sera of patients with SLE and six sera of healthy donors were analyzed using protein microarrays on MAMVE surfaces, ELISA and western-blot analysis. Histones $\mathrm{H} 1$ and $\mathrm{H} 3$ proteins were immobilized at a concentration of $1 \mathrm{mg} / \mathrm{mL}$ onto glass 
slides functionalized with MAMVE at $3 \mathrm{mg} / \mathrm{mL}$ concentration. The diluted sera of eight patients (P1 - P8) were then incubated and antigen-antibody complexes were fluorescently detected with Cy3 anti-human IgG secondary antibody (Figure 4). The diluted sera were also analyzed by ELISA for the detection of anti-histone $\mathrm{H} 1$ and anti-hsitone $\mathrm{H} 3$ antibodies. Both immunoassays showed good repeatability $(\mathrm{CV}=9 \pm 0.1 \%$ for protein microarray, and $\mathrm{CV}=8.5 \pm 0.7 \%$ for ELISA $)$ and reproducibility (CV $=10 \pm 6 \%$ for protein microarray, and CV $=9 \pm 7 \%$ for ELISA), in accordance with the results previously obtained with purified antibodies.

The results shown in Figure 5 indicate the ratio of fluorescence intensity or OD values / cut-off of positivity. The cut-off of positivity was calculated from the mean of the fluorescence intensity, or OD values obtained from the sera of six healthy donors. Seven of the eight sera samples (P1, P2, P4-P8) tested on the MAMVE functionalized protein microarrays were positive for anti-histone $\mathrm{H} 1$ antibodies and all of the sera samples were positive for anti-histone $\mathrm{H} 3$ antibodies. However, with ELISA, only five of the sera samples (P1, P2, P6-P8) were positive for anti-histone $\mathrm{H} 1$ antibodies and four of the sera samples (P2, P6-P8) were positive for anti-histone $\mathrm{H} 3$ antibodies. Only serum P3 was negative for anti-histone $\mathrm{H} 1$ antibodies using both techniques. Concordant results between MAMVE functionalized protein microarrays and ELISA tests were found in $50 \%$ of the sera samples (sera P2, P6, P7 and P8) for anti-histone $\mathrm{H} 1$ and anti-histone $\mathrm{H} 3$ antibody detection. The discrepancy between the two techniques could be explained by the gain in the lower limit of detection for immunoassays performed on MAMVE functionalized surfaces, as the LOD on this surface is 50 fold lower than that of ELISA. However, some positive sera samples in ELISA displayed higher ratios than obtained with MAMVE functionalized protein microarrays: P2, P6 for the detection of anti-histone $\mathrm{H} 3$ antibodies, and P8 for the 
detection of anti-histone $\mathrm{H} 1$ and anti-histone $\mathrm{H} 3$ antibodies. It is likely that these sera contained high levels of anti-histone $\mathrm{H} 1$ and/or $\mathrm{H} 3$ compared to the others. As we observed (cf table 1), ELISA showed a slightly larger dynamic range and sensitivity than the protein microarrays, thus allowing the differentiation of sera samples containing high level of anti-histone antibodies.

For all sera samples, an additional analysis was performed using the western blot technique, which is known to be sensitive for the detection of anti-histone antibodies (AHA) in serum $(26,27)$. The summary of the results obtained with the protein microarrays, ELISA, and western blot is presented in Table 2. For the eight tested sera samples, the data collected shows that concordant results between the protein microarrays and the western blot are found in $75 \%$ of the sera samples (sera P1, P4 - P8), while they are found in $50 \%$ of the samples between the protein microarrays and the ELISA (sera: P2, P6-P8). For the anti-histone $\mathrm{H} 1$ antibodies, concordant results between the western blot protein microarrays and the protein microarrays are found in $100 \%$ of the samples. For the anti-histone H3 antibodies, the P2 serum sample was tested negative with the western blot analysis, whereas it was tested positive with both ELISA and the MAMVE functionalized protein microarrays, and the P3 serum sample was tested positive only on the protein microarrays. This last point should be supported with additional samples, but it is important to note that the results obtained from the MAMVE functionalized protein microarrays are in agreement with one or both reference methods for the detection of anti-histone antibodies in the serum of SLE patients. 


\section{Conclusion}

Miniaturized immunoassays displaying a limit of detection 50 fold lower than traditional ELISA technique were developed on glass slides modified with a MAMVE copolymer. The optimal conditions for the chemical functionalization of the slides were found to be a $3 \mathrm{mg} / \mathrm{mL}$ concentration of MAMVE copolymer, and a concentration of $1 \mathrm{mg} / \mathrm{mL}$ of histone proteins. The density and spatial distribution of the grafted reactive groups (anhydride moieties) on the surface allow for the covalent immobilization of histone proteins which have retained their biological activity. Under these conditions, low abundant anti-histone antibodies present in a small volume of biological samples could be detected. Further analysis are in progress in order to evaluate the exact protein grafting density on the MAMVE functionalized surfaces by immobilizing fluorescent proteins as reference.

This novel surface chemistry was tested for the detection of anti-histone $\mathrm{H} 1$ and anti-histone $\mathrm{H} 3$ autoantibodies in SLE human sera, and the analytical performance was compared to standard immunoassays (ELISA and western-blot). Results indicate that our protein microarray is more sensitive than both standard immunoassays. Moreover, our surfaces compared favourably with some commercially available surfaces (16). In the future, this very promising result needs to be supported by testing a large number of sera samples of various concentrations, as well as other biological models.

Thus, immunoassays on MAMVE functionalized surfaces can be utilized to efficiently detect AHA in human sera samples. Recent studies suggest that over 100 autoantibodies may be present in SLE patients (28), indicating that the small spectrum of autoantibodies that are currently measured are not adequately assessing this complex disease. Therefore, the immobilization strategy developed 
herein may be particularly useful for the parallel screening of a broader range of autoantibodies which would have the potential to provide significantly novel insights into the diagnosis, pathogenesis and prognosis of patients with SLE and other autoimmune diseases $(6,29)$.

\section{Acknowledgments}

This work was supported by grants from Région Rhône-Alpes through its priority program "Sciences Analytiques Appliquées" and from the Centre National de la Recherche Scientifique (France) through its program «Protéomique et Génie des Protéines ». The authors are grateful to $\mathrm{Dr}$ Laura A. Rowe (Institute of Biotechnology, University of Cambridge, UK) for reading the manuscript.

\section{References}

[1] S. F. Kingsmore, Multiplexed protein measurement: technologies and applications of protein and antibody arrays., Nature Reviews Drug Discovery 5 (2006) 310-320.

[2] P. Angenendt, J. Glokler, D. Murphy, H. Lehrach, and D. J. Cahill, Toward optimized antibody microarrays: a comparison of current microarray support materials, Analytical Biochemistry 309 (2002) 253-260.

[3] B. B. Haab, M. J. Dunham, and P. Brown, Protein microarrays for highly parallel detection and quantitation of specific proteins and antibodies in complex solutions, Gennome Biology 2 (2001) research0004.1-0004.13.

[4] G. MacBeath, Protein microarrays and proteomics, Nature Genetics 32 (2002) 526-532. 
[5] W. H. Robinson, L. Steinman, and P. J. Utz, Protein and peptide array analysis of autoimmune disease, Biotechniques (2002) 66-69.

[6] W. H. Robinson, C. DiGennaro, W. Hueber, B. B. Haab, M. Kamachi, E. J. Dean, S. Fournel, D. Fong, M. C. Genovese, H. E. de Vegvar, K. Skriner, D. L. Hirschberg, R. I. Morris, S. Muller, G. J. Pruijn, W. J. van Venrooij, J. S. Smolen, P. O. Brown, L. Steinman, and P. J. Utz, Autoantigen microarrays for multiplex characterization of autoantibody responses, Nat Med 8 (2002) 295-301.

[7] Q.-Z. Li, J. Zhou, A. E. Wandstrat, F. Carr-Johnson, V. Branch, D. R. Karp, C. Mohan, E. K. Wakeland, and N. J. Olsen, Protein array autoantibody profiles for insights into systemic lupus erythematosus and incomplete lupus syndromes, Clinical and Experimental Immunology 147 (2006) 60-70.

[8] H. Zhu, and M. Snyder, Protein chip technology, Curr Opin Chem Biol 7 (2003) 55-63.

[9] S. L. Seurynck-Servoss, A. M. White, C. L. Baird, K. D. Rodland, and R. C. Zangar, Evaluation of surface chemistries for antibody microarrays, Analytical Biochemistry 371 (2007) 105-115.

[10] Q. Z. Li, C. Xie, T. Wu, M. Mackay, C. Aranow, C. Putterman, and C. Mohan, Identification of autoantibody clusters that best predict lupus disease activity using glomerular proteome arrays, J Clin Invest 115 (2005) 3428-39.

[11] W. Hueber, B. A. Kidd, B. H. Tomooka, B. J. Lee, B. Bruce, J. F. Fries, G. Sonderstrup, P. Monach, J. W. Drijfhout, W. J. van Venrooij, P. J. Utz, M. C. Genovese, and W. H. Robinson, Antigen microarray profiling of autoantibodies in rheumatoid arthritis, Arthritis Rheum 52 (2005) 2645-55. 
[12] F. J. Quintana, P. H. Hagedorn, G. Elizur, Y. Merbl, E. Domany, and I. R. Cohen, Functional immunomics: microarray analysis of $\lg G$ autoantibody repertoires predicts the future response of mice to induced diabetes, Proc Natl Acad Sci U S A 101 Suppl 2 (2004) 14615-21.

[13] A. Lueking, O. Huber, C. Wirths, K. Schulte, K. M. Stieler, U. Blume-Peytavi, A. Kowald, K. Hensel-Wiegel, R. Tauber, H. Lehrach, H. E. Meyer, and D. J. Cahill, Profiling of alopecia areata autoantigens based on protein microarray technology, Mol Cell Proteomics 4 (2005) 1382-90.

[14] S. Horn, A. Lueking, D. Murphy, A. Staudt, C. Gutjahr, K. Schulte, A. Konig, M. Landsberger, H. Lehrach, S. B. Felix, and D. J. Cahill, Profiling humoral autoimmune repertoire of dilated cardiomyopathy (DCM) patients and development of a diseaseassociated protein chip, Proteomics 6 (2006) 605-13.

[15] P. Angenendt, J. Glokler, J. Sobek, H. Lehrach, and D. J. Cahill, Next generation of protein microarray support materials: evaluation for protein and antibody microarray applications, J Chromatogr A 1009 (2003) 97-104.

[16] I. Balboni, C. Lim, J. D. Tenenbaum, and P. J. Utz, Evaluation of microarray surfaces and arraying parameters for autoantibody profiling, Proteomics 8 (2008) 3443-3449.

[17] S.-y. Seong, and C.-y. Choi, Current status of protein chip development in terms of fabrication and application, Proteomics 3 (2003) 2176-2189.

[18] V. Dugas, G. Depret, B. Chevalier, X. Nesme, and E. Souteyrand, Immobilization of single-stranded DNA fragments to solid surfaces and their 
repeatable specific hybridization: covalent binding or adsorption? Sensors and Actuators, B: Chemical 101 (2004) 112-121.

[19] G. El Khoury, E. Laurenceau, V. Dugas, Y. Chevolot, Y. Merieux, M.-C. Duclos, E. Souteyrand, D. Rigal, J. Wallach, and J.-P. Cloarec (2007) in 29th Annual International Conference of the IEEE Engineering in Medicine and Biology, Vol. 1, pp. 2242-2246, IEEE, Lyon.

[20] D. Saboulard, V. Dugas, J. Broutin, M. Jaber, E. Souteyrand, J. Sylvestre, and M. Delcourt, High-throughput site-directed mutagenesis using oligonucleotides synthesized on DNA-chips, BioTechniques 39 (2005) 363-368.

[21] L. Allard, V. Cheynet, G. Oriol, B. Mandrand, T. Delair, and F. Mallet, Versatile method for production and controlled polymer-immobilization of biologically active recombinant proteins, Biotechnology And Bioengineering 80 (2002) 341-348.

[22] K. Isosaki, N. Seno, I. Matsumoto, T. Koyama, and S. Moriguchi, Immobilization Of Protein Ligands With Methyl Vinyl Ether Maleic-Anhydride Copolymer, Journal Of Chromatography 597 (1992) 123-128.

[23] S. Soultani-Vigneron, V. Dugas, M. H. Rouillat, J. Fédollière, M. C. Duclos, E. Vnuk, M. Phaner-Goutorbe, V. Bulone, J. R. Martin, J. Wallach, and J. P. Cloarec, Immobilisation of oligopeptidic probes for microarray implementation: characterisation by FTIR, Atomic Force Microscopy and 2D fluorescence, Journal of Chromatography B 822 (2005) 304-310.

[24] P. Moncharmont, and P. Monneron, Essai d'un témoin multiparamétrique au laboratoire de qualification biologique du don, Revue Française des Laboratoires 1998 (1998) 45-47. 
[25] R. R. Sokal, and J. F. Rolhf, Biometry: the principles and practice of statistics in biological research, W H Freeman \& Co, New York, 1981.

[26] W. Egner, The use of laboratory tests in the diagnosis of SLE, Journal Of Clinical Pathology 53 (2000) 424-432.

[27] I. Ghedira, H. Landolsi, A. Mankai, N. Fabien, and M. Jeddi, Antihistones antibodies in systemic lupus erythematosus, comparison of three assays: Elisa, dot blot and immunoblot, Pathologie Biologie 54 (2006) 148-154.

[28] Y. Sherer, A. Gorstein, M. J. Fritzler, and Y. Shoenfeld, Autoantibody explosion in systemic lupus erythematosus: more than 100 different antibodies found in SLE patients, Semin Arthritis Rheum 34 (2004) 501-37.

[29] W. Hueber, P. J. Utz, L. Steinman, and W. H. Robinson, Autoantibody profiling for the study and treatment of autoimmune disease, Arthritis Res 4 (2002) 290-5. 


\section{Figures captions}

Figure 1. Covalent immobilization of histone proteins $(\mathrm{H} 1$ or $\mathrm{H} 3)$ on NHS ester $(\mathrm{A})$ and MAMVE copolymer (B) functionalized glass slides.

Figure 2. Validation of the histone $\mathrm{H} 3$ / anti-histone $\mathrm{H} 3$ model and the determination of the low limit of detection of anti-histone H3 polyclonal antibody by ELISA technique and immunoassays on NHS ester functionalized surfaces. Thresholds were calculated from the mean of OD $(492 \mathrm{~nm})$ or fluorescence intensity values of the dilution buffer.

A) ELISA technique: Histone $\mathrm{H} 3$ was coated at $5 \mu \mathrm{g} / \mathrm{mL}\left(3.5 \times 10^{-11} \mathrm{~mol} ; 100 \mu \mathrm{L}\right)$ and $10 \mu \mathrm{g} / \mathrm{mL}\left(7 \times 10^{-11} \mathrm{~mol} ; 100 \mu \mathrm{L}\right)$. OD values were measured at $492 \mathrm{~nm}$ versus the dilution factor of rabbit anti-histone $\mathrm{H} 3$ antibody $\left(10^{-8}\right.$ to $\left.10^{-2}\right)$..

B) Immunoassays on NHS ester functionalized surfaces: Immobilization of histone $\mathrm{H} 3$ at $0.5 \mathrm{mg} / \mathrm{mL}\left(3.5 \times 10^{-11} \mathrm{~mol}\right)$ and $1 \mathrm{mg} / \mathrm{mL}\left(7 \times 10^{-11} \mathrm{~mol}\right)$. The mean of the fluorescence intensity was measured at $532 \mathrm{~nm}$ versus the dilution factor of rabbit anti-H3 antibody $\left(10^{-8}\right.$ to $\left.10^{-2}\right)$.

Figure 3. Effect of MAMVE concentration on the detection of anti-histone $\mathrm{H} 3$ antibodies on glass slides. Histone $\mathrm{H} 3$ protein was covalently immobilized at 0.5 and $1 \mathrm{mg} / \mathrm{mL}$.

Figure 4. Panel A: Image of the miniaturized immunoassays on the MAMVE functionalized glass slide for the detection of anti-histone $\mathrm{H} 1$ and anti-histone $\mathrm{H} 3$ antibodies from human sera samples. Image analysis was performed with GenePix Pro 6.0 software.

Panel B: Array layout used for the miniaturized immunoassays from SLE patient sera (P1 to P8: rounds with small dots), healthy donor sera (S1 to S6: white rounds) and buffer B (PBS-BSA 1\%: gray rounds) as negative control for secondary antibody 
non-specific adsorption. Each serum was tested in duplicate on each slide. Lanes 1 and 2 were not functionalized with histone proteins (non-specific adsorption of antibodies). Lanes 3 and 4 were functionalized with histone $\mathrm{H} 1$ at $1 \mathrm{mg} / \mathrm{mL}$. Lanes 6 and 7 were functionalized with histone $\mathrm{H} 3$ at $1 \mathrm{mg} / \mathrm{mL}$. Detection of human antibodies was performed with goat anti-human IgG antibody fluorescently labelled with Cy3.

Figure 5. Comparison between MAMVE functionalized protein microarrays and ELISA for the detection of anti-histone $\mathrm{H} 1$ and $\mathrm{H} 3$ antibodies in human sera samples, expressed in the ratio = signal value/cutoff.

(Cutoff $=1$ a.u $=$ mean of negative control signals $+t_{0.01} \mathrm{SD} \sqrt{ }(\mathrm{n}+1 / \mathrm{n})$; $t$ : Student's $t$ distribution for $\alpha=0.01$, with $\mathrm{n}-1$ degree of freedom; $\mathrm{n}=6$ negative control sera). 


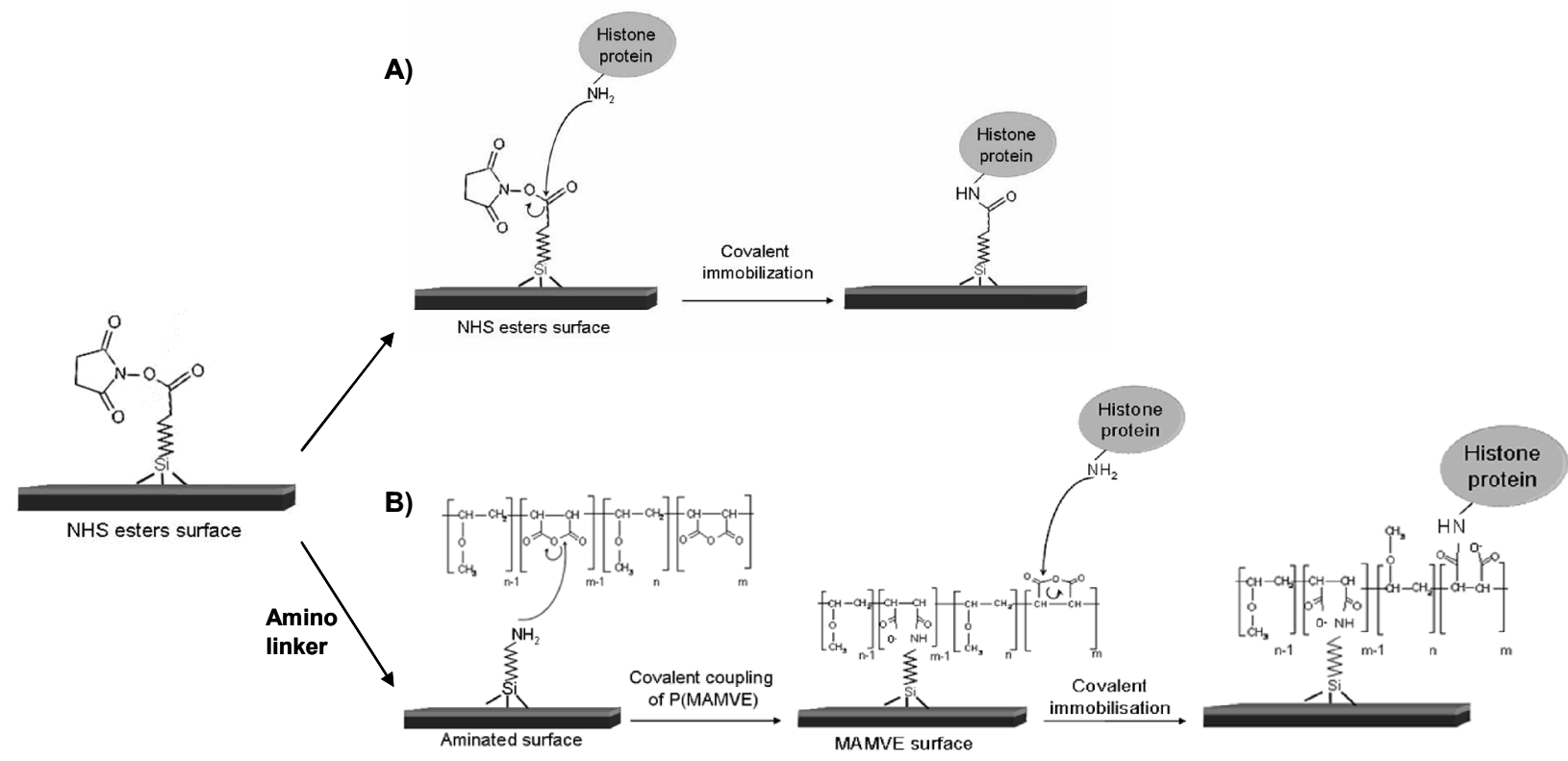

Figure 1 


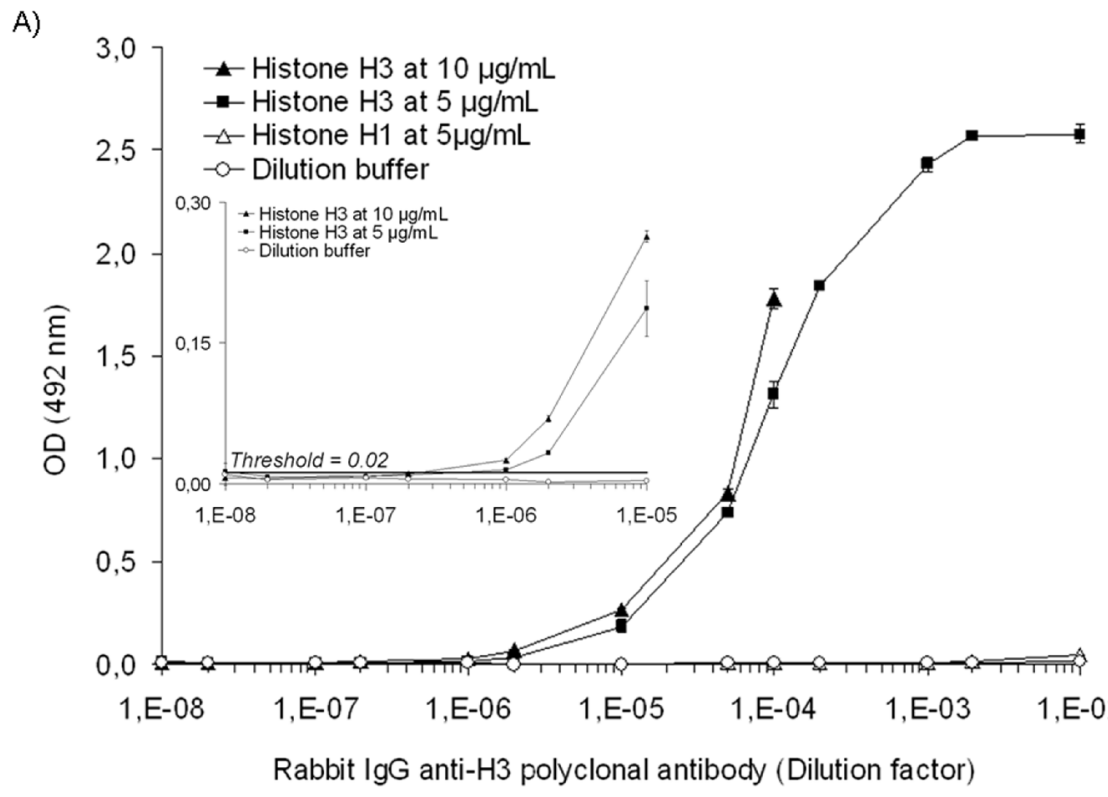

B)

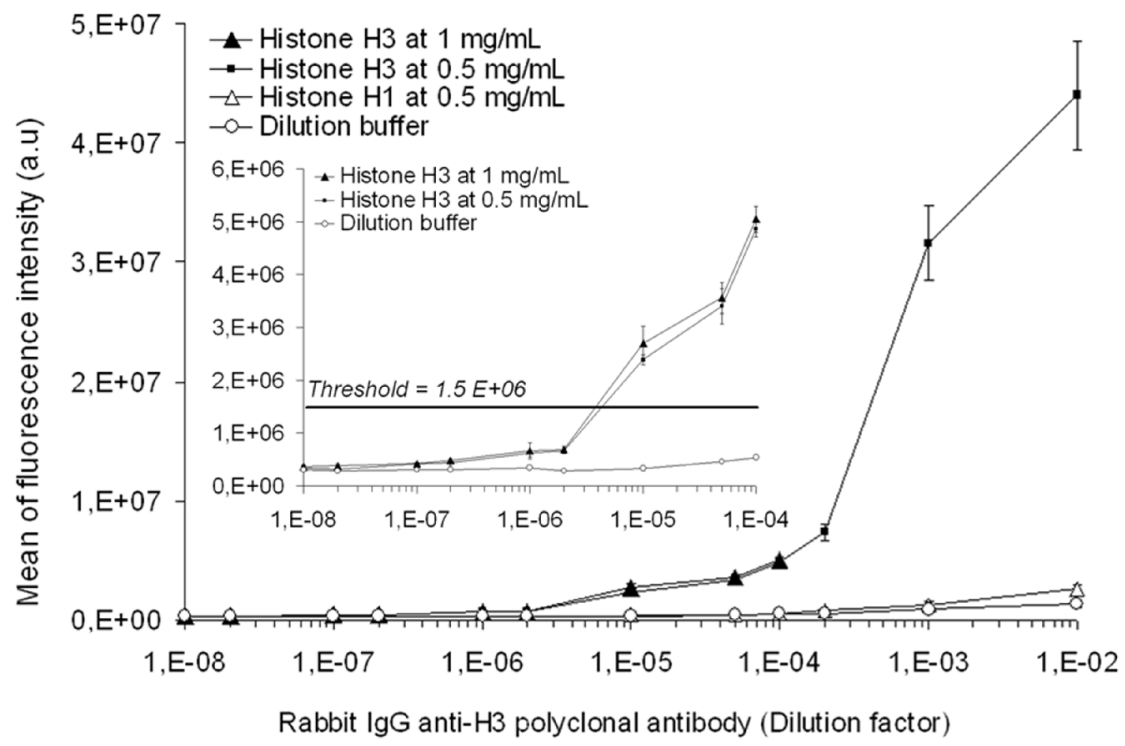

Figure 2 

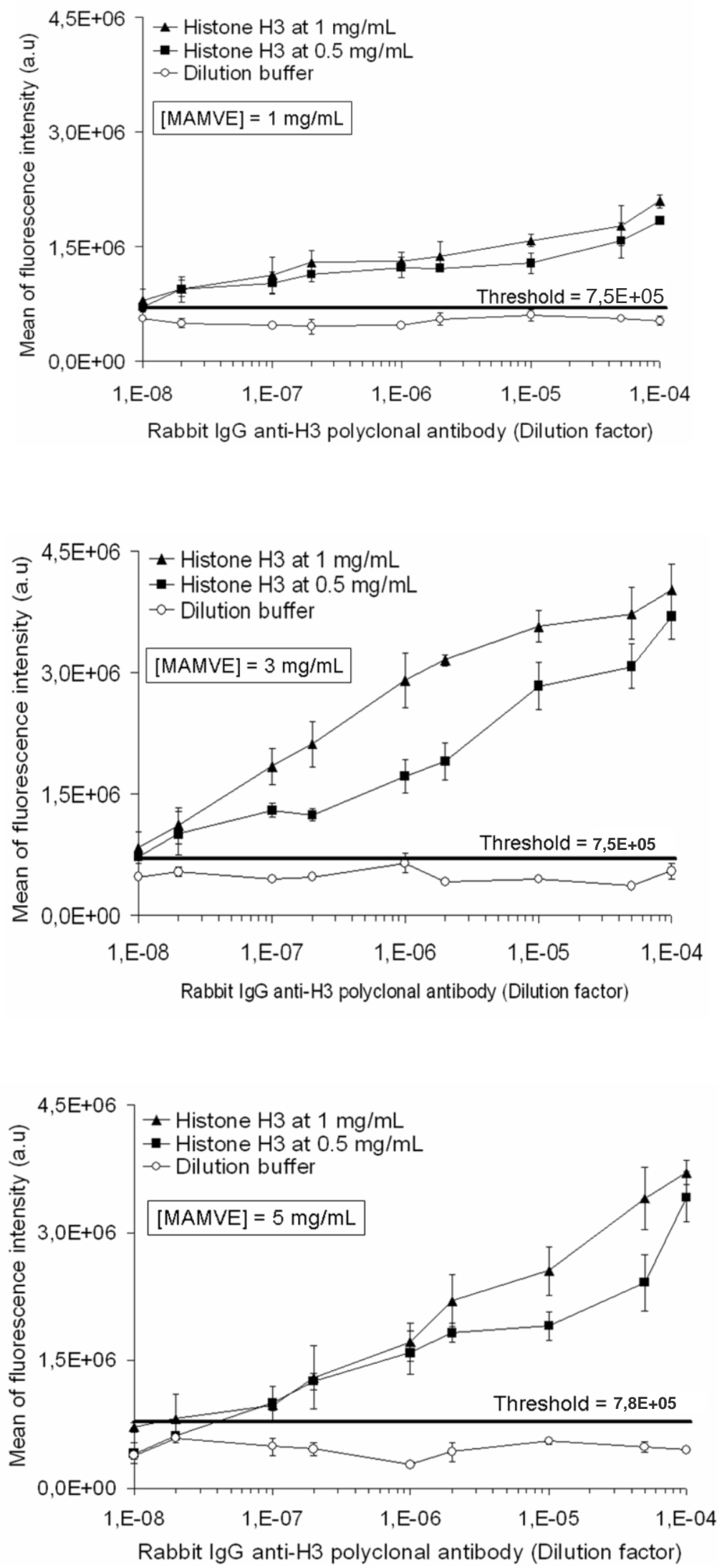

Figure 3 
A.

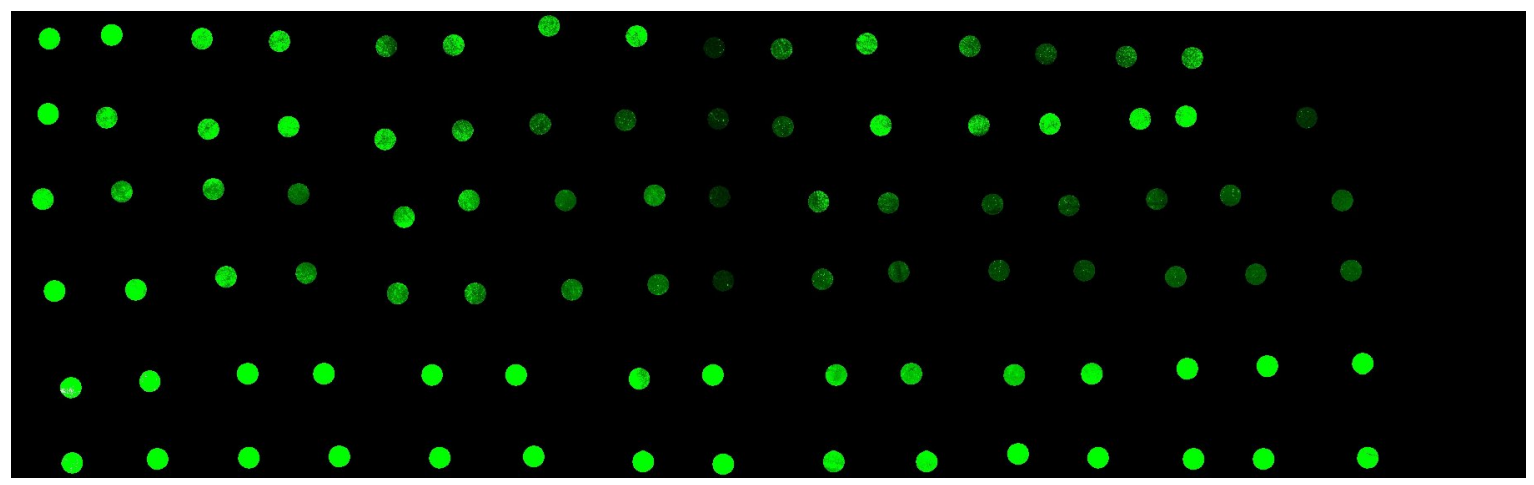

B.

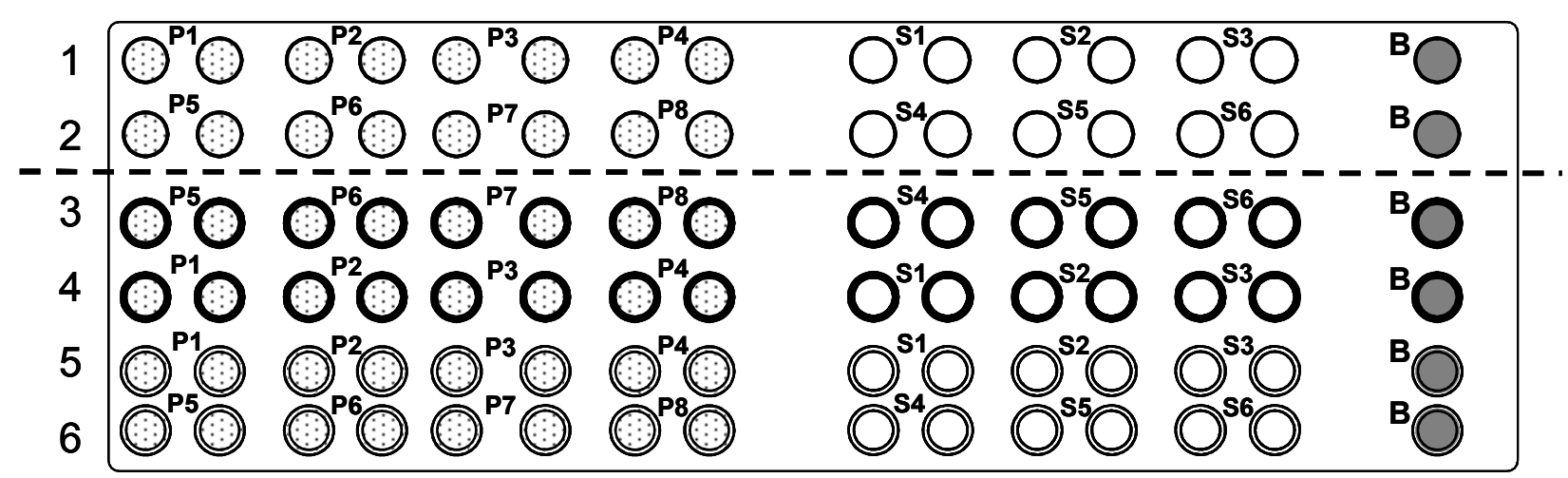

Figure 4 
Classical ELISA

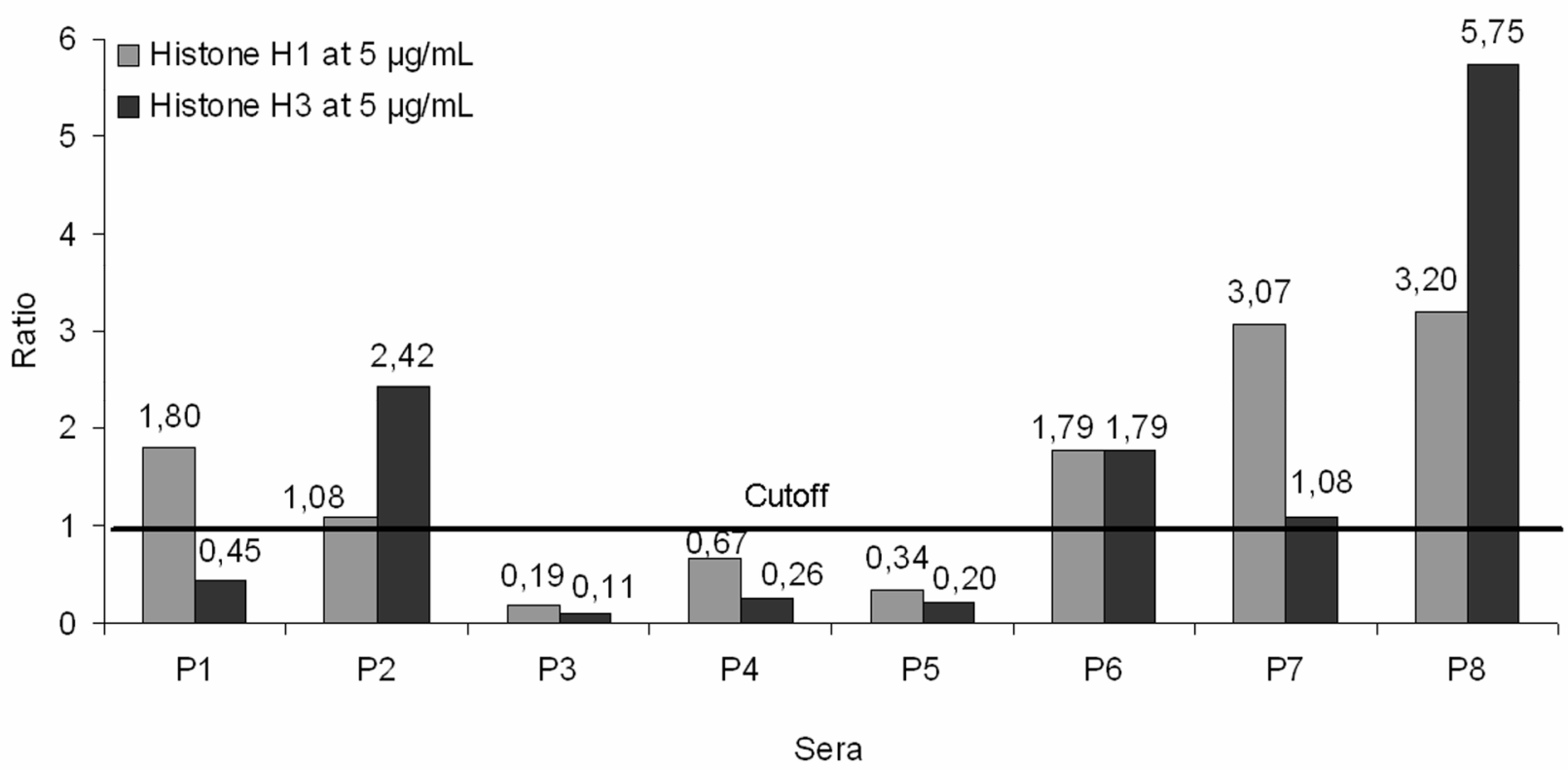

Protein microarrays (MAMVE surface)

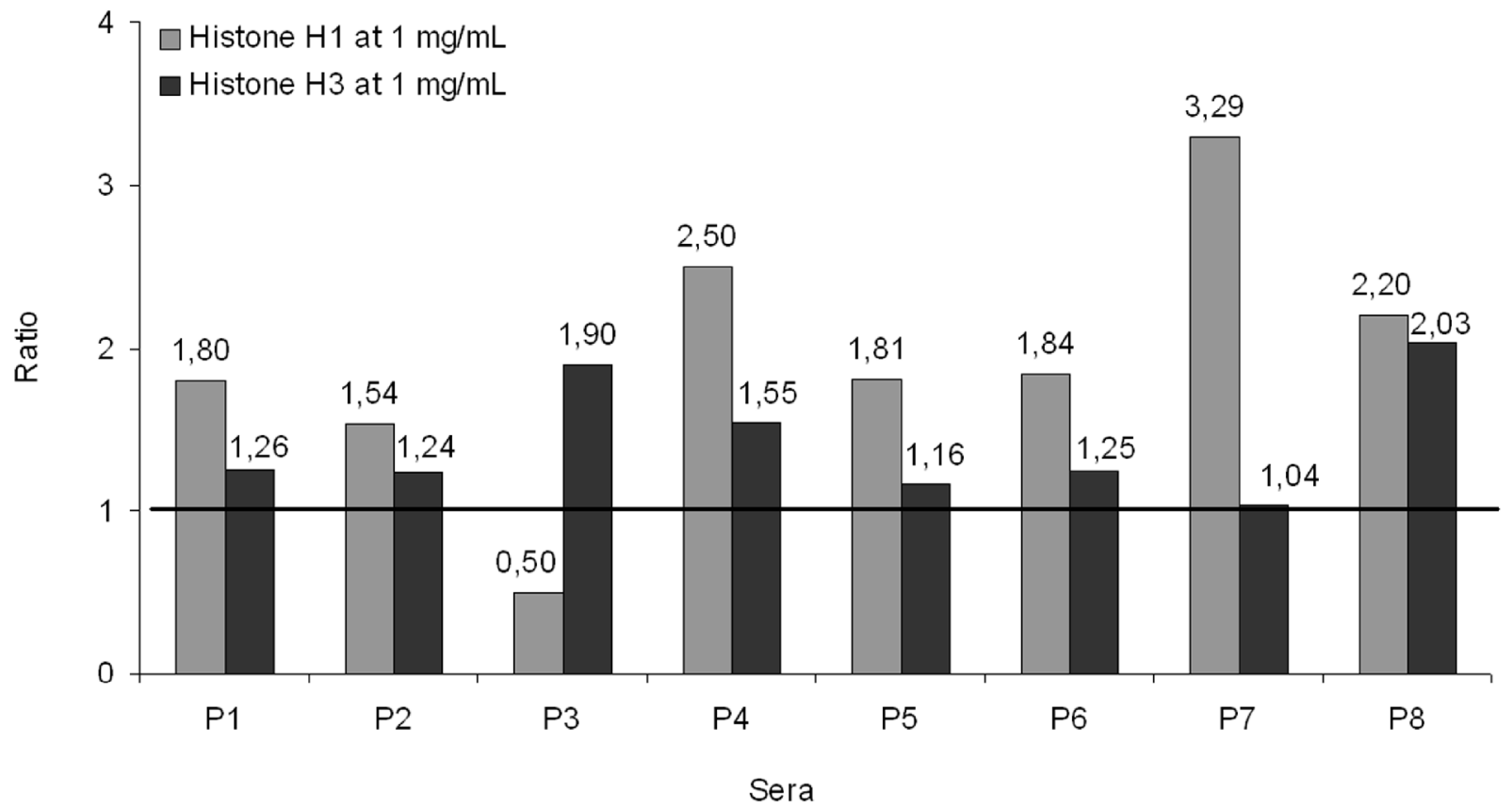

Figure 5 


\section{Table 1}

Analytical performances of ELISA compared to immunoassays on protein microarrays with different surface chemistries

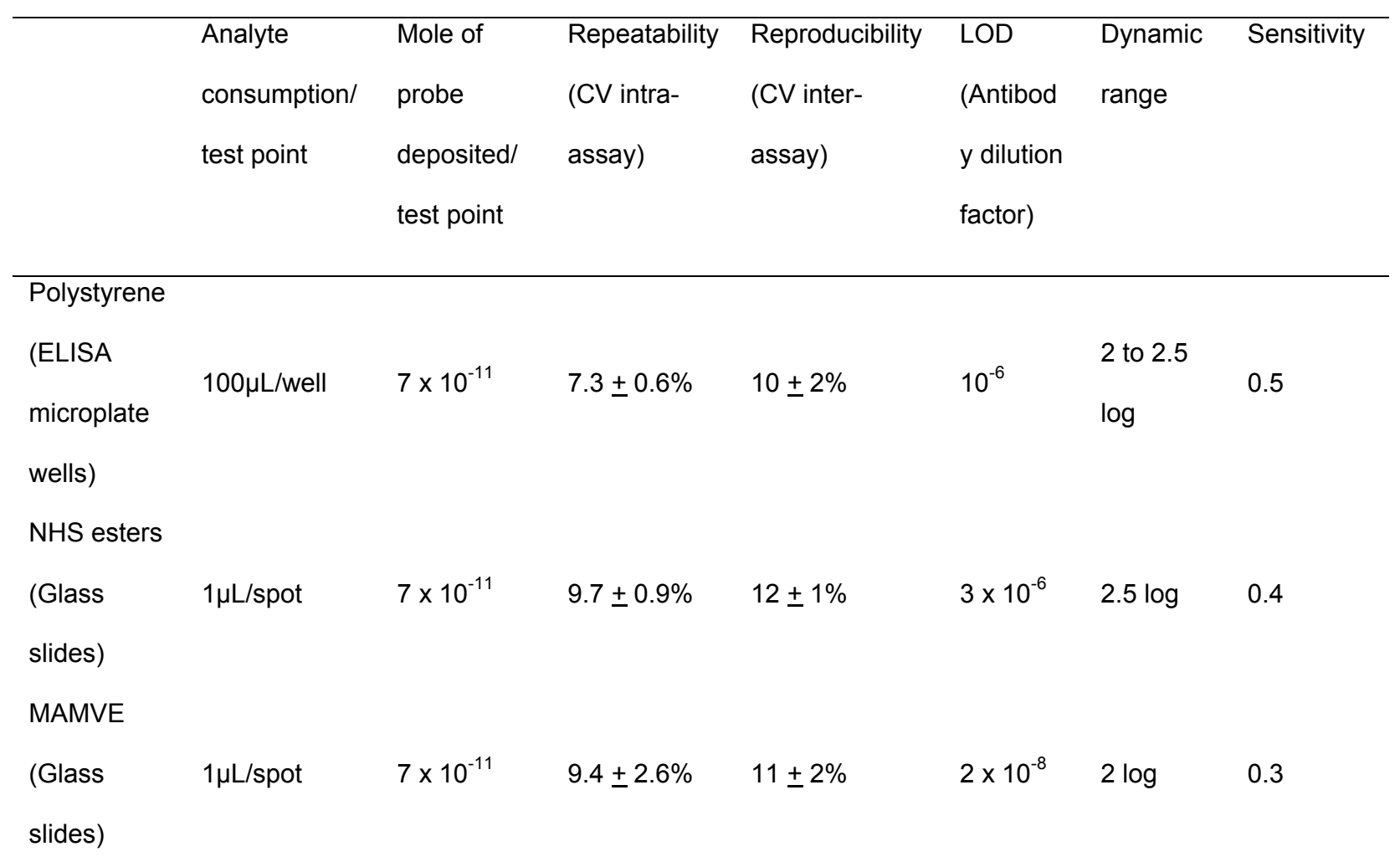




\section{Table 2}

Summary of results obtained on protein microarrays, ELISA and western blot techniques for anti-histone $\mathrm{H} 1$ and $\mathrm{H} 3$ antibodies detection; $(+)$ detection or (-) absence of antibodies

\begin{tabular}{|c|c|c|c|c|c|c|}
\hline \multirow{4}{*}{ Antibodies } & \multicolumn{2}{|c|}{$\begin{array}{l}\text { Protein } \\
\text { microarrays }\end{array}$} & \multicolumn{2}{|l|}{ ELISA } & \multicolumn{2}{|l|}{$\begin{array}{l}\text { Western } \\
\text { blot }\end{array}$} \\
\hline & Anti- & Anti- & Anti- & Anti- & Anti- & Anti- \\
\hline & histone & histone & histone & histone & histone & histone \\
\hline & $\mathrm{H} 1$ & $\mathrm{H} 3$ & $\mathrm{H} 1$ & $\mathrm{H} 3$ & $\mathrm{H} 1$ & $\mathrm{H} 3$ \\
\hline \multicolumn{7}{|l|}{ Patients } \\
\hline $\mathrm{P} 1$ & + & + & + & - & + & + \\
\hline $\mathrm{P} 2$ & + & + & + & + & + & - \\
\hline P3 & - & + & - & - & - & - \\
\hline P4 & + & + & - & - & + & + \\
\hline P5 & + & + & - & - & + & + \\
\hline P6 & + & + & + & + & + & + \\
\hline P7 & + & + & + & + & + & + \\
\hline P8 & + & + & + & + & + & + \\
\hline
\end{tabular}

